\title{
Presence of benthic dinoflagellates around coastal waters of Jeju Island including newly recorded species
}

\author{
Md. Mahfuzur Rahman Shah ${ }^{1}$, So-Jung $\mathrm{An}^{2}$ and Joon-Baek Lee ${ }^{2, *}$ \\ ${ }^{1}$ Jeju Sea Grant Center, Jeju National University, Jeju 690-756, Korea \\ ${ }^{2}$ Department of Earth and Marine Sciences, College of Ocean Sciences, Jeju National University, Jeju 690-756, Korea
}

\begin{abstract}
A study on the presence of benthic dinoflagellates in the intertidal zone along the coasts of Jeju Island, Korea was conducted during 2011 and 2012. Identification and taxonomic observations were made of the benthic dinoflagellate samples using light and epifluorescence microscopy. Thirty-seven dinoflagellate taxa belong to five orders, nine families, 18 genera and 30 species, which are new records for Korean waters, were detected in this study. The detailed nomenclature, references, distribution, and illustrations are presented here. The commonly occurring genera were Amphidinium, Coolia, Ostreopsis, Prorocentrum, and Thecadinium. Among the recorded species, 26 were found only in sand sediment, seven in macroalgal samples, and four were found in both sand and macroalgal samples. Of the 37 species, nine were potentially toxic. These results suggest that diversified benthic dinoflagellates including several potentially toxic species occur in sand sediment and macroalgae in the intertidal zone along the coasts of Jeju Island. The morphological features of the identified species were more or less similar to observations made by previous studies in Korea and elsewhere. The presence of known toxic species may indicate a potential risk of toxicity in the marine ecosystem of Jeju Island. The present study can be helpful for further detailed taxonomic, toxicological, molecular phylogenetic studies and may help in the management and conservation of Jeju Island's marine ecosystem.
\end{abstract}

Key words: benthic dinoflagellates; intertidal zone; Jeju Island; new record; potentially toxic

\section{INTRODUCTION}

Marine benthic dinoflagellates are of tremendous global economic significance. At present, benthic dinoflagellates are receiving much attention in terms of microalgal monitoring due to the problems encountered with potentially harmful benthic or bentho-planktonic species which lead to the economic loss by killing fish/shellfish through toxic blooms and subsequently human health in subtropical to tropical coastal areas. The most well known human intoxication due to benthic dinoflagellates is ciguatera fish poisoning (Hallegraeff 1993, Lehane and Lewis 2000, Godhe et al. 2002, Gilbert et al. 2005). Benthic epiphytic dinoflagellates are known to be present in tropical and subtropical regions of the Pacific Ocean, Indian Ocean, and the Caribbean where they are found associated with seagrasses, green, brown, and red algae, as well as dead coral and sediment (Fukuyo 1981, Morton and Faust 1997, Turquet et al. 1998, Pearce et al. 2001, Aligizaki et al. 2008). However, some species also live in temperate regions (Pistocchi et al. 2011, Selina and Levchenko 2011). Many benthic flagellates are abundant in the intertidal substrata and their contributions to benthic and shallow marine ecosystems may be significant. The occurrence of http://dx.doi.org/10.5141/ecoenv.2013.347

(1) $\$$ This is an Open Access article distributed under the terms of the Creative Commons Attribution Non-Commercial Licens (http://creativecommons.org/licenses/by-nc/3.0/) which permits unrestricted non-commercial use, distribution, and reproduction in any medium, provided the original work is properly cited.
Received 29 October 2013, Accepted 20 November 2013

*Corresponding Author

E-mail: jblee@jejunu.ac.kr

Tel: +82-64-754-3435 


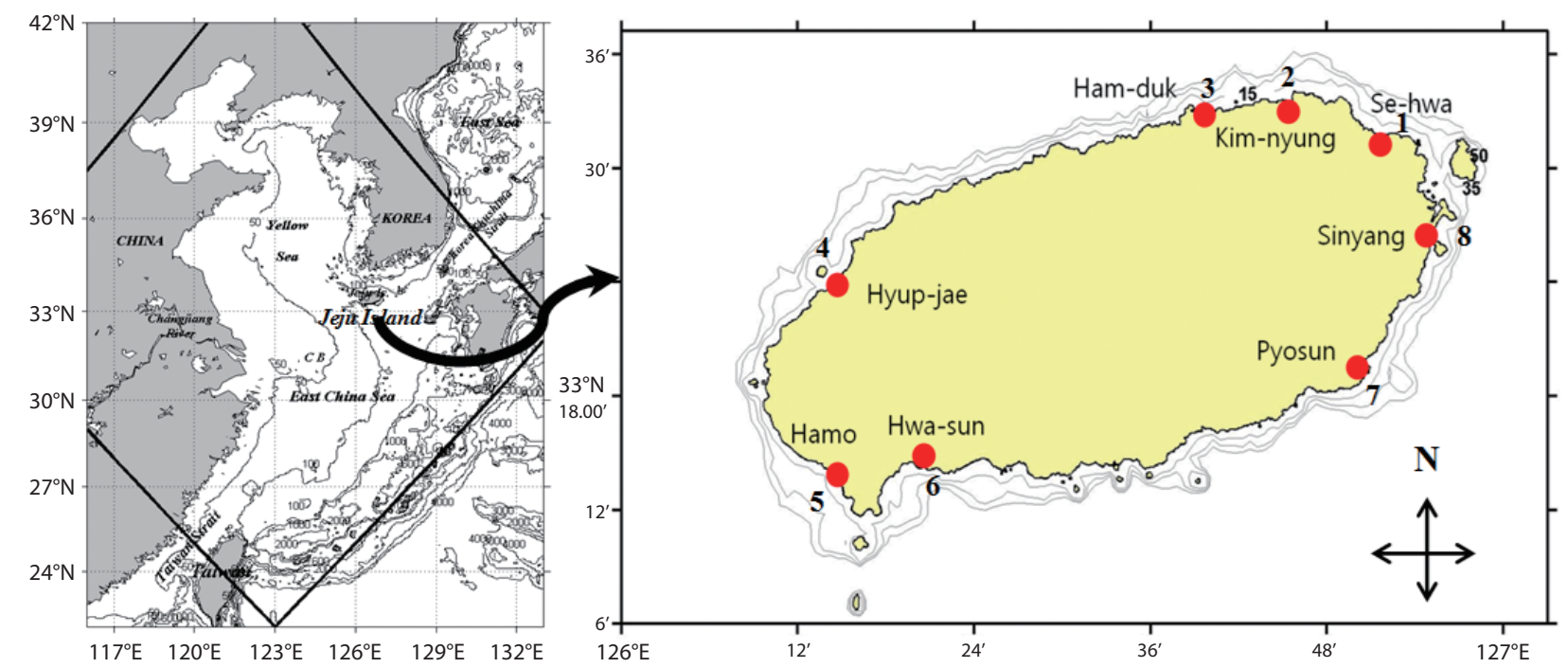

Fig. 1. Map showing Jeju Island, Korea and locations of the eight sampling stations along the coasts of Jeju Island.

epiphytic and benthic dinoflagellates in temperate waters has been reported as evidence of increasing water temperature (Rhodes 2011, Jeong et al. 2012a). Several benthic flagellates species of the genera Ostreopsis, Coolia, Prorocentrum, and Amphidinium are known to be potentially toxic (Fukuyo 1981, Besada et al. 1982, Faust 1995, Mohammad-Noor et al. 2007). Therefore, studying their abundance and potential toxic effects in intertidal waters is important.

Jeju Island is a volcanic island located about $80 \mathrm{~km}$ south of the Korean peninsula in the southwestern sea of Korea with an area of about $1,830 \mathrm{~km}^{2}$. The coastline is mainly composed of rocky shore and sandy beaches with a few sand tidal flats. Jeju Island belongs to the temperate region classified based on air temperature. The Tsushima Warm Current (TWC), a branch of the Kuroshio Current with high water temperature and high salinity, strongly affects the adjacent sea of Jeju Island (Pang et al. 1996). Previously, the toxic dinoflagellates recorded from Korean temperate waters were planktonic but potentially toxic benthic sand dwelling and epiphytic species have not been well documented. Information on existing diversity and distribution patterns of benthic toxic/nontoxic dinoflagellates near Jeju Island is limited and sparse. To date, no toxic event caused by a marine benthic dinoflagellate has been reported from Jeju Island. Total 153 planktonic dinoflagellates were recorded from Korean waters by previous studies (Shim et al. 1981, Han and Yoo 1983a, 1983b, Yoo and Lee 1986, Lee et al. 1993, Shim 1994). Recently, Kim et al. (2011), Jeong et al. (2012a, 2012b), Kang et al. (2013) and Lim et al. (2013) described 6 benthic epiphytic dinoflagellates in the coastal waters of Jeju Island. However, in-depth information on taxonomy, distribution, diversity, and molecular phylogeny of benthic dinoflagellates from Korean waters has to be collected. Thus, the aim of this study was to document benthic dinoflagellates from the intertidal zone of Jeju Island coastal waters as part of a project called "Survey and Excavation of Korean Indigenous Species" of the National Institute of Biological Resources (NIBR) under the Ministry of Environment of Korea.

\section{MATERIALS AND METHODS}

\section{Study sites and sample collection}

This study was carried out from March 2011 to February 2012 in the intertidal zone along the coasts of Jeju Island, Korea. Monthly sampling was carried out at eight designated stations (beaches) (Fig. 1) and 480 samples of sand sediment and macroalgae were collected during the lowest low tide. A brief description of the characteristics, latitudes, and longitudes of the sampling stations is presented in Table 1. Sand sediment samples (50-150 g wet weight) were collected from depths of 3-4 $\mathrm{cm}$ on sandy beaches using a plastic tube sample corer. The samples were transferred to plastic bottles with ambient seawater. In the laboratory, the sediment samples were vigorously shaken for 1 minute and the material was passed through 200 and $100 \mu \mathrm{m}$ mesh sieves to remove large particles and finally passed through a $20 \mu \mathrm{m}$ mesh sieve. The material 
retained by the sieve was resuspended in sterile filtered seawater in a Petri dish for live cell examination and isolation (modification of a method of Selina and Hoppenrath 2008).

To survey epiphytic dinoflagellates, we collected 20$100 \mathrm{~g}$ wet weight macroalgae (red, brown, and green) on the intertidal zone of the sampling stations by hand picking and placing them into separate plastic Ziploc bags with ambient seawater. Epiphytic dinoflagellates were separated from the macroalgae by vigorous shaking of the macroalgae into a plastic container with $200 \mathrm{ml}$ of fresh filtered seawater for 1 minute to dislodge the attached dinoflagellate cells, and then we followed the procedure described above to extract the dinoflagellates from the sand sediment.

\section{Dinoflagellate identification}

Freshly-collected living dinoflagellates were isolated by the micropipette-washing method, placed on slide glass covered with a cover slip, and the morphometric features were observed under transmitted light with bright field and phase-contrast at $\times 400$ magnification and photographed using a microscope (Axioplan 2; Carl Zeiss, Oberkochen, Germany) equipped with a digital camera (Axiocam ERc5s; Carl Zeiss). Both the dorsal and ventral sides of each dinoflagellate were examined. Cell size and some morphometric measurements were obtained from micrographs using Carl Zeiss ZEN Lite software (Carl Zeiss). Thecal plate patterns of armored dinoflagellates were identified using Calcofluor White M2R (Fluka, Buchs, Switzerland) (Fritz and Triemer 1985). The Calcofluor stained cells were examined using an epifluorescence (violet excitation at $430 \mathrm{~nm}$, blue emission at $490 \mathrm{~nm}$ ) mi- croscope (Axioplan 2; Carl Zeiss) equipped with a digital camera (Axiocam ICm 1; Carl Zeiss). Unarmored dinoflagellates were identified based on morphological features such as body contour and proportion, cingulum displacement, sulcus extension and direction on the epitheca, and presence and location of specific organelles. Dinoflagellates were identified using previously published schemes (Fukuyo 1981, Faust 1995, Horiguchi 1995, Faust 1996, Steidinger and Tangen 1997, Holmes 1998, Chinain et al. 1999, Faust et al. 1999, Hoppenrath 2000a, 2000b, Hansen et al. 2001, Faust and Gulledge 2002, Murray and Patterson 2002, Murray and Patterson 2004, Hoppenrath et al. 2007a, 2007b, Mohammad-Noor et al. 2007, Al-Yamani and Saburova 2010).

\section{RESULTS}

Thirty seven benthic dinoflagellate species belonging to 18 genera, including Amphidienella, Amphidiniopsis, Amphidinium, Cabra, Coolia, Durinskia, Gambierdiscus, Gymnodinium, Gyrodinium, Heterocapsa, Katodinium, Ostreopsis, Oxyrrhis, Polykrikos, Prorocentrum, Testudodinium, Thecadinium, and Togula, were isolated and identified from the intertidal zone of Jeju Island's coastal waters (Table 2). Among the identified genera, the most dominant and diverse benthic dinoflagellate genus was Amphidinium with 10 species followed by Prorocentrum (six species), and Amphidiniopsis and Togula with two species each. Durinskia, Gambierdiscus, and Thecadinium comprised two species each. However, Amphidienella, Coolia, Cabra, Gymnodinium, Gyrodinium, Heterocapsa, Katodinium, Ostreopsis, Oxyrrhis, Polykrikos, and Testudodinium were monospecific. Only three genera

Table 1. Summary of sampling stations in the intertidal zone along the coasts of Jeju Island, Korea

\begin{tabular}{|c|c|c|c|c|}
\hline Locations & Station number & Latitude & Longitude & Characteristics of sampling stations \\
\hline SE-HWA & 1 & $33^{\circ} 31^{\prime} 29.86^{\prime \prime} \mathrm{N}$ & $126^{\circ} 51^{\prime} 40.50^{\prime \prime} \mathrm{E}$ & Sandy beach with fine white sand and volcanic rocks \\
\hline KIMNYUNG & 2 & $33^{\circ} 33^{\prime} 29.64^{\prime \prime} \mathrm{N}$ & $126^{\circ} 45^{\prime} 35.23^{\prime \prime} \mathrm{E}$ & $\begin{array}{l}\text { Sandy beach comprising white, very fine sand and rocky } \\
\text { shore }\end{array}$ \\
\hline HAM-DUK & 3 & $33^{\circ} 32^{\prime} 32.94^{\prime \prime} \mathrm{N}$ & $126^{\circ} 40^{\prime} 12.27^{\prime \prime} \mathrm{E}$ & White sandy beach with fine white sand \\
\hline HYUP-JAE & 4 & $33^{\circ} 23^{\prime} 38.88^{\prime \prime} \mathrm{N}$ & $126^{\circ} 14^{\prime} 23.02^{\prime \prime} \mathrm{E}$ & Large sandy beach with volcanic rocks \\
\hline HAMO & 5 & $33^{\circ} 12^{\prime} 39.86^{\prime \prime} \mathrm{N}$ & $126^{\circ} 15^{\prime} 38.23^{\prime \prime} \mathrm{E}$ & $\begin{array}{l}\text { Very small beach with coarse black and white sand with } \\
\text { volcanic rocks }\end{array}$ \\
\hline HWA-SUN & 6 & $33^{\circ} 14^{\prime} 22.38^{\prime \prime} \mathrm{N}$ & $126^{\circ} 19^{\prime} 55.67^{\prime \prime} \mathrm{E}$ & $\begin{array}{l}\text { Small beach with coarse black and white sand with volca- } \\
\text { nic rocks }\end{array}$ \\
\hline PYOSUN & 7 & $33^{\circ} 19^{\prime} 34.73^{\prime \prime} \mathrm{N}$ & $126^{\circ} 50^{\prime} 29.30^{\prime \prime} \mathrm{E}$ & Large sandy beach with fine white sand \\
\hline SINYANG & 8 & $33^{\circ} 31^{\prime} 29.86^{\prime \prime} \mathrm{N}$ & $126^{\circ} 51^{\prime} 40.50^{\prime \prime} \mathrm{E}$ & Sandy beach with fine white sand and volcanic rocks \\
\hline
\end{tabular}




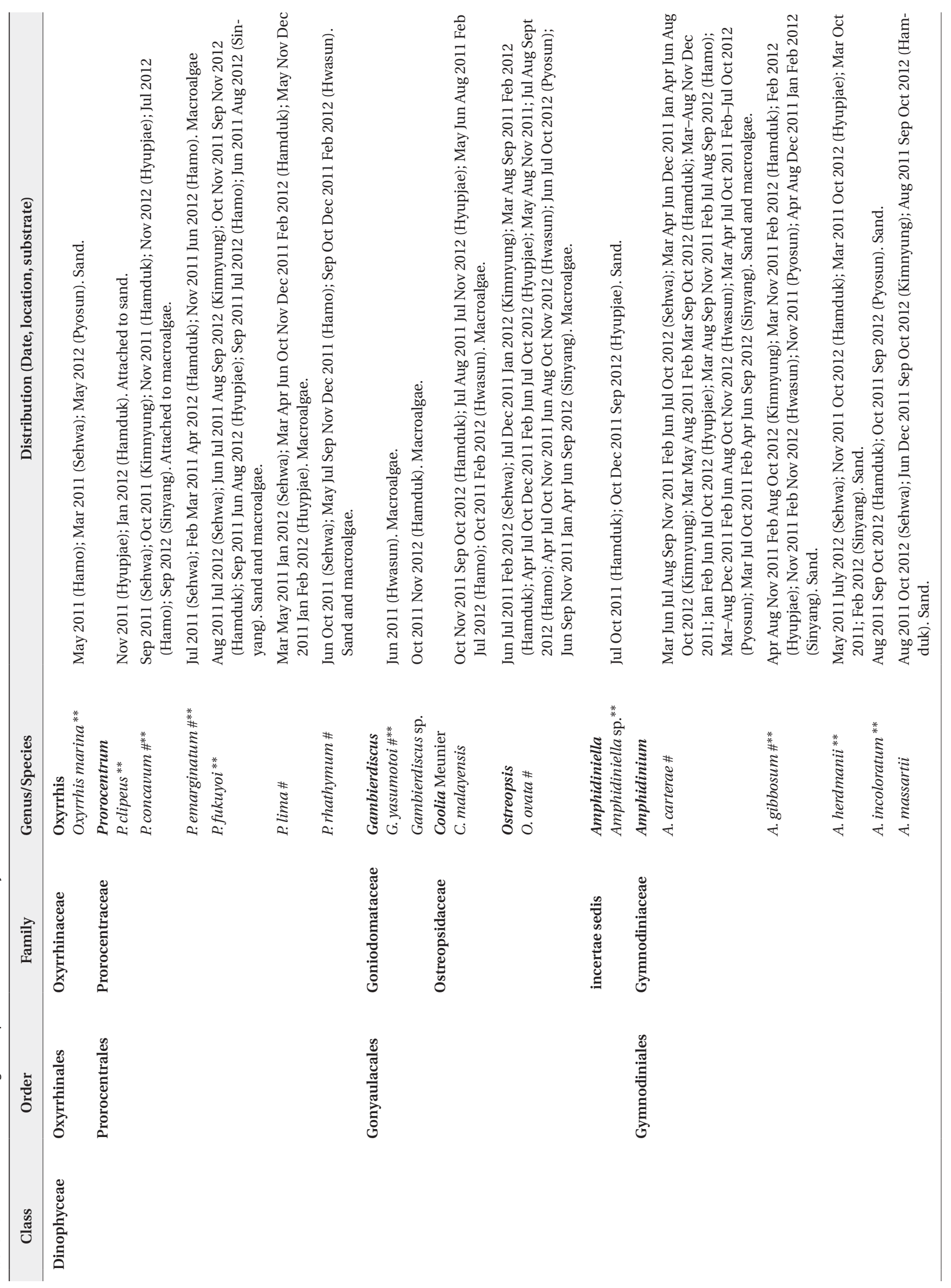




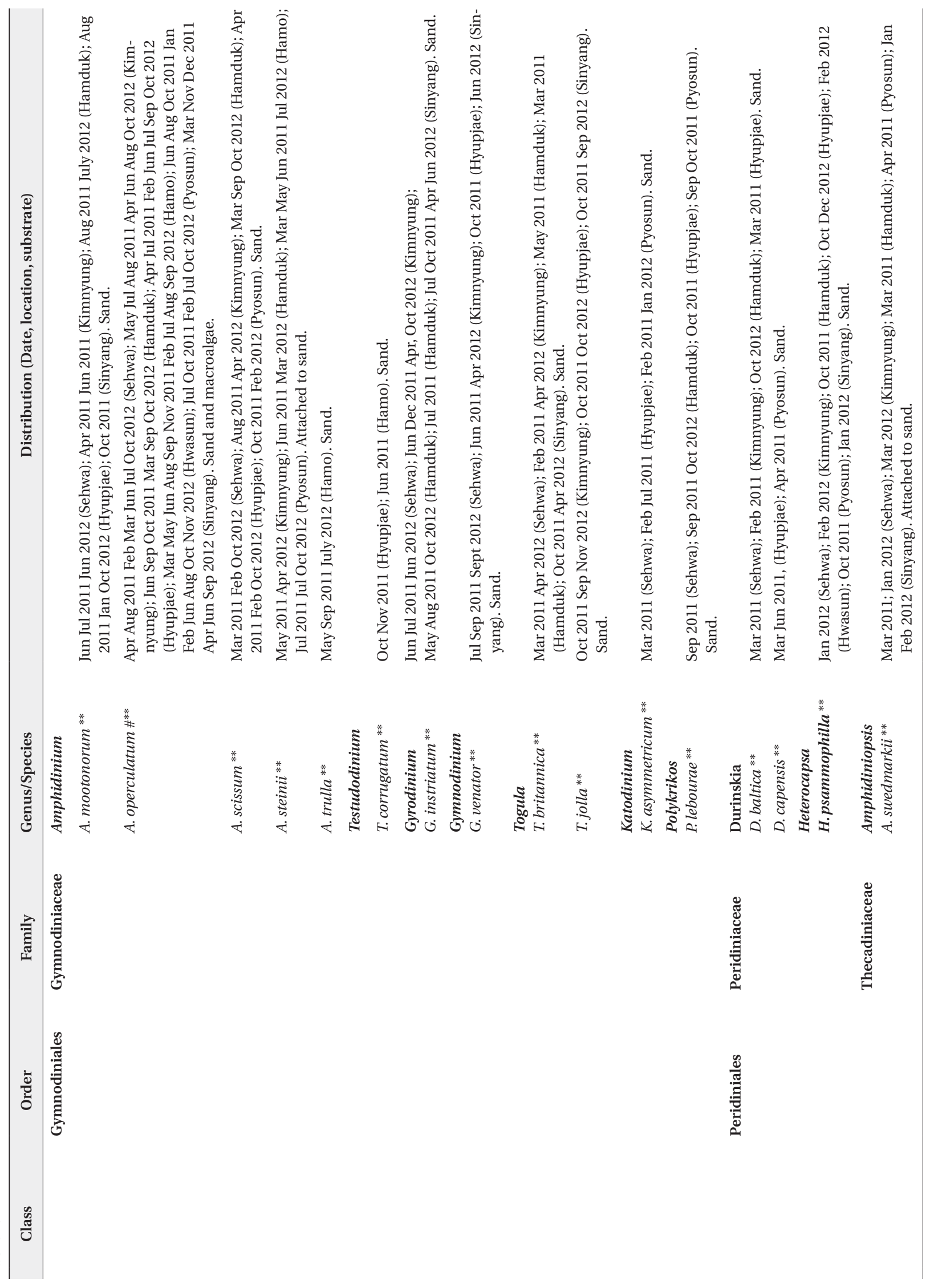




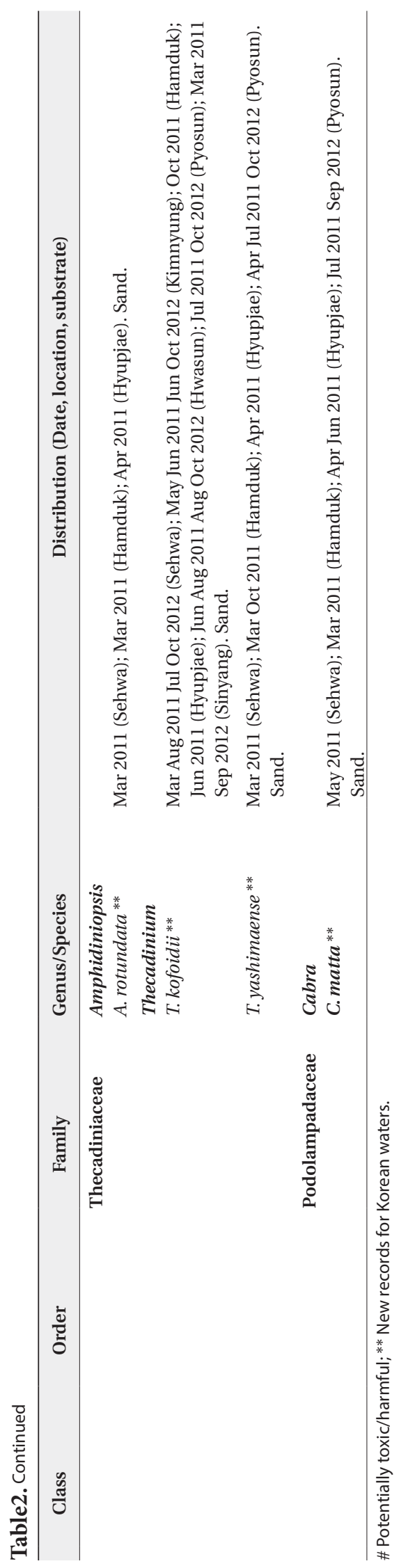

viz., Amphidinium, Coolia, and Ostreopsis including the species Amphidinium carterae, A. operculatum, Coolia malayensis, and O. ovata were commonly found at most sampling stations. Two species belonging to the genus Gambierdiscus, G. yasumotoi, and Gambierdiscus sp. were recorded rarely.

Of the 37 species identified in this study, 26 were recorded from only sand sediment, seven species were associated with macroalgae, and four species belonging to Amphidinium (A. carterae and A. operculatum) and Prorocentrum (P. rhathymum) were found both in sand and macroalgal samples. Coolia, Gambierdiscus, and Ostreopsis were exclusively found on macroalgal samples. Amphidinium and Prorocentrum were found on macroalgae as well as sand sediment. Only three genera such as Amphidinium, Coolia, and Ostreopsis occurred frequently as noted by the dominance of species such as Amphidinium carterae, A. operculatum, Coolia malayensis, and O. ovata at all sampling stations.

Thirty taxa from the aforementioned benthic dinoflagellate genera constitute new records of benthic marine microflora in this study area and the systematic and distrubution are presented in Table 2. Among the identified species, 26 were recorded from only sand sediment, seven were associated with macroalgae and four were found in both sand and macroalgal samples (Table 2). Taxonomic information, illustrations, classification, references, basionyms, synonyms of the identified benthic dinoflagellates are described below.

\section{Genus Oxyrrhis Dujardin 1841}

\section{Oxyrrhis marina Dujardin 1841 (Fig. 2A and 2B) \\ Synonyms: Oxyrrhis tentaculifera Conrad 1939; Oxyr- rhis maritima Van Meel 1969.}

References: Dujardin 1841, p 347, pl. 5: 4; Kofoid and Swezy 1921, pp 117-119, fig. 3; Lebour 1925, p 19, pl. I: 6a-e; Dodge 1982, p 111, fig. 13E-F.

Specimen examined: Slide LJB2012-07 at the National Institute of Biological Resources (NIBR), Incheon.

Description: Cell elongated to oval shape. Anterior end broadly conical and posterior end is asymmetrical. Posterior end of cell contains a tentacular lobe. Transverse and longitudinal flagella originate to the left and right of the lobe, respectively. Food vacuoles are observed in the cytoplasm. The nucleus is located near the anterior end of cell. The cell is unarmored, nonphotosynthetic, colorless or slightly pinkish.

Size: Length $(\mathrm{L})(\mu \mathrm{m}): 12-30(23.7 \pm 3.4$, mean \pm standard deviation); Width $(\mathrm{W})(\mu \mathrm{m})$ : 10-28 (15.5 \pm 2.8$)$ 

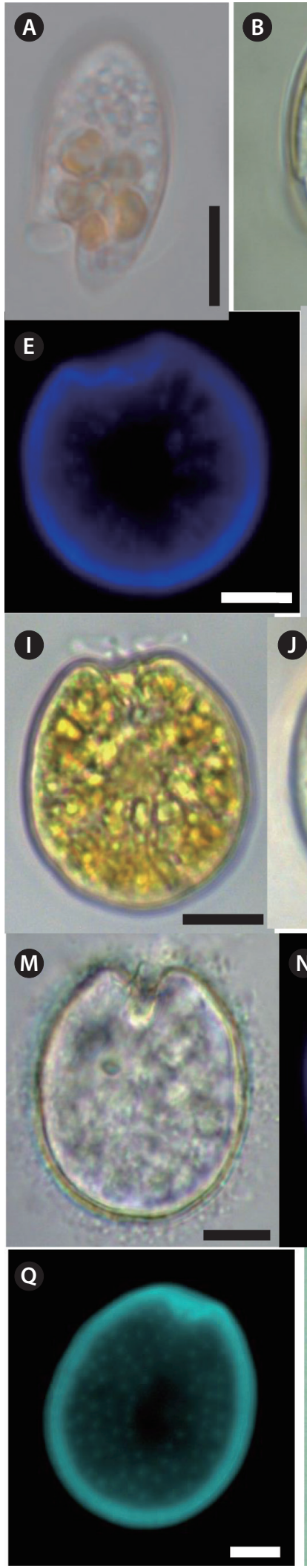

B
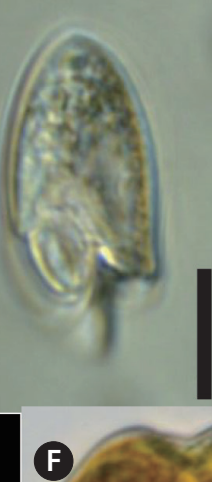

J
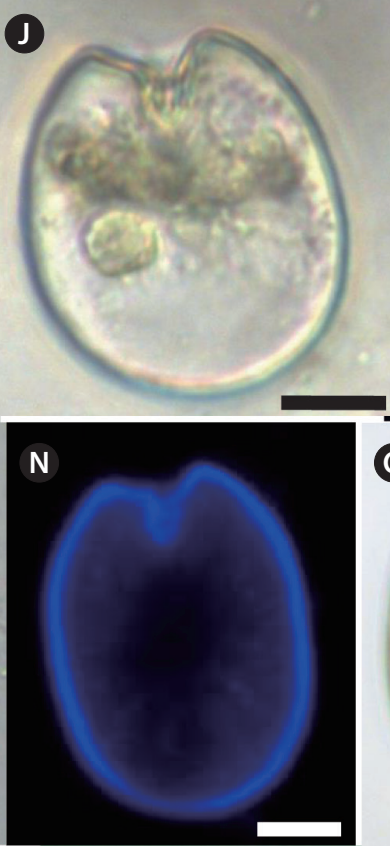

R

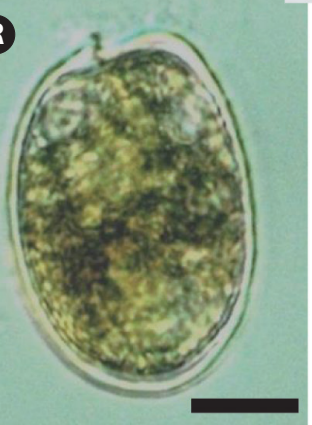

C

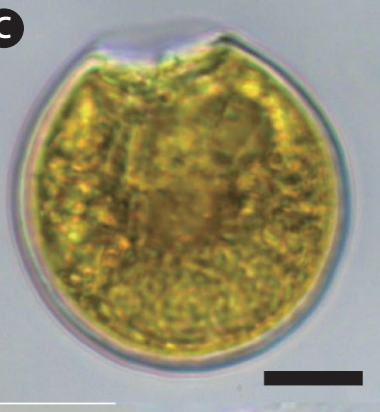

G

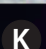

K
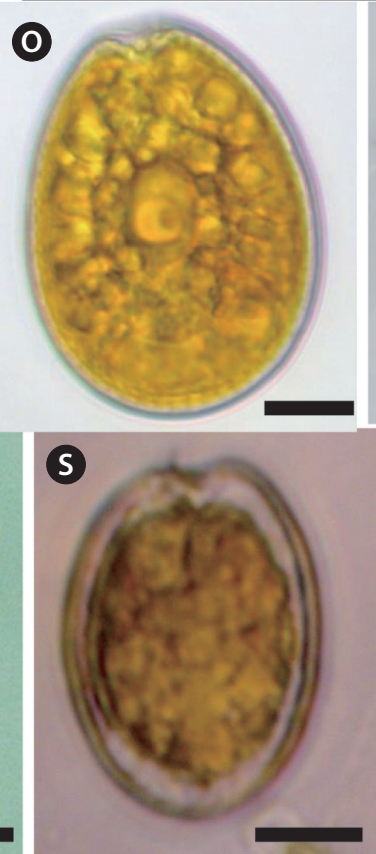

D

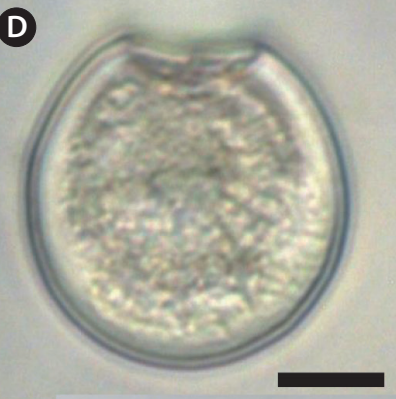

(H)
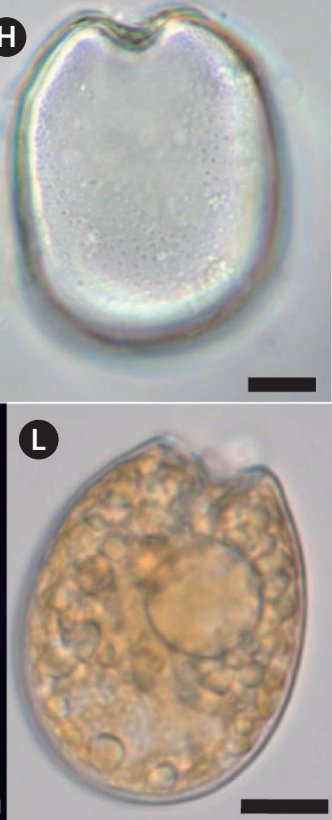

P

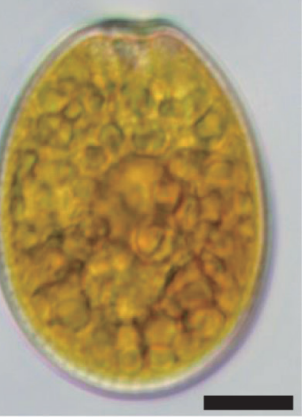

T

Fig. 2. Light micrographs of the genera Oxyrrhis and Prorocentrum (present study). A and B: Oxyrrhis marina, C-E: Prorocentrum clipeus, F-H: Prorocentrum concavum, I-K: Prorocentrum emarginatum, L-N: Prorocentrum fukuyoi, O-Q: Prorocentrum lima, R-T: Prorocentrum rhathymum, Photos E, K, N, Q, and T: epifluorescence. Scale bars, $10 \mu \mathrm{m}$. 


\section{Genus Prorocentrum Ehrenberg 1833}

Prorocentrum clipeus Hoppenrath 2000 (Fig. 2C-2E)

References: Hoppenrath 2000a, pp 30-31, figs. 1-12. Specimen examined: Slide LJB2012-04 at the NIBR, Incheon.

Description: Armored photosynthetic dinoflagellate. The cell is nearly round. Cell contains yellow-brown chloroplasts, a pusule, a small apical spine, and a central pyrenoid. The periflagellar region is wide-arc shape. The large kidney-shaped nucleus is located posteriorly.

Size: $L(\mu \mathrm{m})$ : $30-35$ (33.8 \pm 0.6$) ; W(\mu \mathrm{m})$ : 32-36.5 (34.0 $\pm 0.4)$.

\section{Prorocentrum concavum Fukuyo 1981 (Fig. 2F-2H)}

Synonym: Prorocentrum arabianum Morton and Faust 2002.

References: Fukuyo 1981, pp 968-969, figs. 13-19, 49; Faust et al. 1999, p 4, fig. 2a-g; Mohammad-Noor et al. 2007, pp 635-639, figs. 3a-j, 14a-c.

Specimen examined: Slide LJB2012-05 at the NIBR, Incheon.

Description: Armored phototsynthetic dinoflagellate with golden-brown chloroplasts. The cell is broadly ovoidal in the valve view, widest behind the middle. Two cupshaped pyrenoids are present at the anterior center and just beneath the valves. The anterior margin is concave. Both valves have fine depressions covering the whole surface. Many trichocyst pores scattered over the valve except the central area, but are denser near the margin.

Size: $L(\mu \mathrm{m}): 45.4-51.3(44.1 \pm 1.2) ; \mathrm{W}(\mu \mathrm{m})$ : 38-48.7 $(39.6 \pm 1.7)$.

Harmful effects: Produces three diol esters of okadaic acid (Hu et al. 1993) and ichthyotoxin (Yasumoto et al.1987).

\section{Prorocentrum emarginatum Fukuyo 1981 (Fig. 2I-2K)}

References: Fukuyo 1981, p 968, figs. 8-12, 48; Faust 1990, p 549, figs. 1-4, 29; Hansen et al. 2001, pp 38-39, pl. 3G, 3H, 6E; Larsen and Nguyen 2004, p 58, pl. 4: 1-3; Mohammad-Noor et al. 2007, pp 639-640, figs. 4a-j, 15a-b.

Specimen examined: Slide LJB2011-15 at the NIBR, Incheon.

Description: Armored photosynthetic dinoflagellate with golden-brown chloroplasts, central pyrenoid, and posterior nucleus. Cells are broadly oval to rotundate. Valve surface is smooth. The periflagellar area is deep and V-shaped and contains a wing like structure. The right valve has an inclined, rectangular flagellar structure and the left valve is concave and deeply indented. Both valves are concave at the center, and the anterior end is deeply indented.

Size: $L(\mu \mathrm{m}):$ 35-40 (30.35 \pm 0.4); W $(\mu \mathrm{m}): 28-34$ (26.75 $\pm 0.8)$.

Harmful effects: Potentially toxic species (Hansen et al. 2001). Turquet (1997) found low hemolytic and fibroblast activity in a crude extract of cells from the southwestern Indian Ocean.

Prorocentrum fukuyoi Murray and Nagahama 2007 (Fig. 2L-2N)

Reference: Murray et al. 2007, pp 93-95, figs. 1-13.

Specimen examined: Slide LJB2011-16 at the NIBR, Incheon.

Description: Armored photosynthetic dinoflagellate. Cells are narrow oval to almost oblong shape. The apical area is narrow, slightly curved, V-shaped, and a spine is present. Valve surface is smooth. Rows of large size pores radiate towards the center. There is a round pusule near the flagella origin. Large plastids radiate toward the periphery of the cell. There is a pyrenoid with a ring-shaped starch-sheath.

Size: $L(\mu \mathrm{m}): 30-42(37.1 \pm 1.9) ; W(\mu \mathrm{m}): 25-32(31.20 \pm$ $0.9)$.

Prorocentrum lima (Ehrenberg) Dodge 1975 (Fig. 2O2Q)

Synonyms: Cryptomonas lima Ehrenberg 1860, Exuviella marina Cienkowski 1881, Dinopyxis laevis Stein 1883, Exuviella lima (Ehrenberg) Butschii 1885, Exuviella laevis (Stein) Schroder 1900, Exuviella cincta Schiller 1918, Exuviella ostenfeldii Schiller 1931, Exuviella caspica Kiselev 1940, and Prorocentrum marinum Dodge \& Bibby 1973.

References: Dodge 1982, p 30, fig. 2G-H; Hansen et al. 2001, p 40, pl. 5: A-D; Larsen and Nguyen 2004, p 59, pl. 5: $1-5$.

Description: Armored photosynthetic dinoflagellate with golden-brown chloroplasts, a prominent central pyrenoid, and a posterior nucleus. Cells are oval to oblong. The cell margin is round at the posterior end and flat at the anterior end. The periflagellar area is small with a V-shaped depression. The thecal surface is smooth with scattered pores that are absent in the center. Marginal pores are present. Both valves are concave.

Size: $L(\mu \mathrm{m}): 34.5-43.3(41.8 \pm 1.3) ; \mathrm{W}(\mu \mathrm{m}): 27-33$ (31.2 $\pm 1.5)$.

Harmful effects: DSP producer (Prokic et al. 1998, Sechet et al. 1998) and produces okadaic acid and dinophysistoxin (Marr et al. 1992, Barbier et al. 1999). 
Prorocentrum rhathymum Loeblich III, Sherley et Schmidt 1979 (Fig. 2R-2T)

References: Loeblich et al. 1979, pp 115-116, 118-119, figs. 8-13; Fukuyo 1981, p 968, figs. 5-7, 47; Cortés-Altamirano and Sierra-Beltrán 2003, pp 223-224, figs. 1o-q, 3; Mohammad-Noor et al. 2007, pp 652-653, figs. 10a-i, 2la-b.

Specimen examined: Slide LJB2012-06 at the NIBR, Incheon.

Description: Armored photosynthetic dinoflagellate. Cell is broadly oval. The left valve has an indentation at the anterior end. A small spine is located at the ventral side of the auxillary pore. The nucleus is located in the posterior of the cell, and the pyrenoid is central. The thecal surface is smooth, and two different pore sizes are present. The larger pores are radially arranged and perpendicular to the valve margin.

Size: L ( $\mu \mathrm{m}): 32.5-40.3$ (34.5 \pm 1.3$)$; W $(\mu \mathrm{m}): 20-25$ (22.7 \pm 0.8 ).

Harmful effects: Produce toxins with hemolytic activity (Nakajima et al. 1981), and water-soluble fast-acting toxins (Tindall et al. 1989).

\section{Genus Gambierdiscus Adachi and Fukuyo 1979}

\section{Gambierdiscus yasumotoi Holmes 1998 (Fig. 3A-3E)}

References: Holmes 1998, pp 663-664, figs. 1-8; Hansen et al. 2001, p 55, pl. 9: D-F.

Specimen examined: Slide LJB2011-01 at the NIBR, Incheon.

Description: Armored photosynthetic dinoflagellate. Cells are globular in general. Cells are circular to ovoid in apical view. The thecal surface is smooth and covered with numerous small pores. The cingulum is median to premedian, deep, and narrow. Sulcus is broad and indented. The plate formula: po, 3'7”, 6c, 6s, 5”, 1p, 2"'”. The apical pore plate (po) has a long fish-hook-shaped pore. Numerous small golden-brown chloroplasts are present. Cell contains 2-3 large hyaline pusules centrally located or in the hypocone.

Size: L ( $\mu \mathrm{m})$ : 56-67.5 (61.60 \pm 3.2); W ( $\mu \mathrm{m})$ : 46-58.5 (52 $\pm 2.6)$.

Harmful effects: G. yasumotoi produces maitotoxins (Holmes et al. 1998).

\section{Gambierdiscus sp. (Fig. 3F-3H)}

Description: Cells are large, rounded obliquely ellipsoidal in apical view, lenticular in ventral view, anterio-pos- teriorly compressed. Epitheca and hypotheca are almost equal in size. The cingulum is deep, narrow, and ascending, and the sulcus is deep and short. The thecal surface is smooth and covered with numerous small pores.

Size: $L(\mu \mathrm{m})$ : $69.5-81(77.0 \pm 3.2) ; \mathrm{W}(\mu \mathrm{m}): 76.5-87.2$ $(79.1 \pm 2.6)$.

\section{Genus Coolia Meunier 1919}

Coolia malayensis Leaw, P.-T.Lim et Usup 2010 (Fig. 3I3N)

References: Leaw et al. 2010, pp 164-165, figs. 2-4.

Specimen examined: Slide LJB2011-09 at the NIBR, Incheon.

Description: Armored photosynthetic dinoflagellate. Cells are small, round in dorsoventral and lateral views. Thecal surface is smooth, irregularly scattered with large pores. The inner part of the thecal pores has scattered, very fine perforations. The plate formula: po, 3', 7", 6c, 6s (?), 5"', 2"”.

Size: $L(\mu \mathrm{m})$ : 26.5-35.0 (30.5 \pm 3.2); $W(\mu \mathrm{m}): 25-33.5$ $(28.3 \pm 2.6)$.

\section{Genus Ostreopsis Schmidt 1901}

\section{Ostreopsis ovata Fukuyo 1981 (Fig. 30-3S)}

References: Fukuyo 1981, p 971, figs. 35-38, 54, 55; Faust et al. 1996, pp 1057-1059, figs. 16-23; Larsen and Nguyen 2004, pp 115-117, pl. 20: 1-6, pl. 21: 5; Penna et al. 2005, pp 216-217, fig. 4; Aligizaki and Nikolaidis 2006, pp 719-722, fig. 2.

Specimen examined: Slide LJB2011-10 at the NIBR, Incheon.

Description: Armored photosynthetic dinoflagellate with many golden chloroplasts. Cells are tear-shaped, ovoid to oblong, pointed toward the ventral area. Epitheca and hypotheca about equal in size.The plate formula is: Po, 3', 7”, 6c, 6?s, 5"', 2"', 1p, The thecal plates are thin and delicate. The thecal surface is smooth, ornamented with minute, evenly scattered pores. Nucleus is located at the posterior end of the cell. One or two pussels observed in the dorsal part of the cell.

Size: $L(\mu \mathrm{m}):$ 30-64 (51.46 \pm 2.1$)$; W $(\mu \mathrm{m}): 20-58$ (34.5 \pm 1.7).

Harmful effects: Produces a toxic butanol-soluble compound (Elbrächter and Faust 2002) related to human health problems in tourists (Aligizaki and Nikolaidis 2006). 


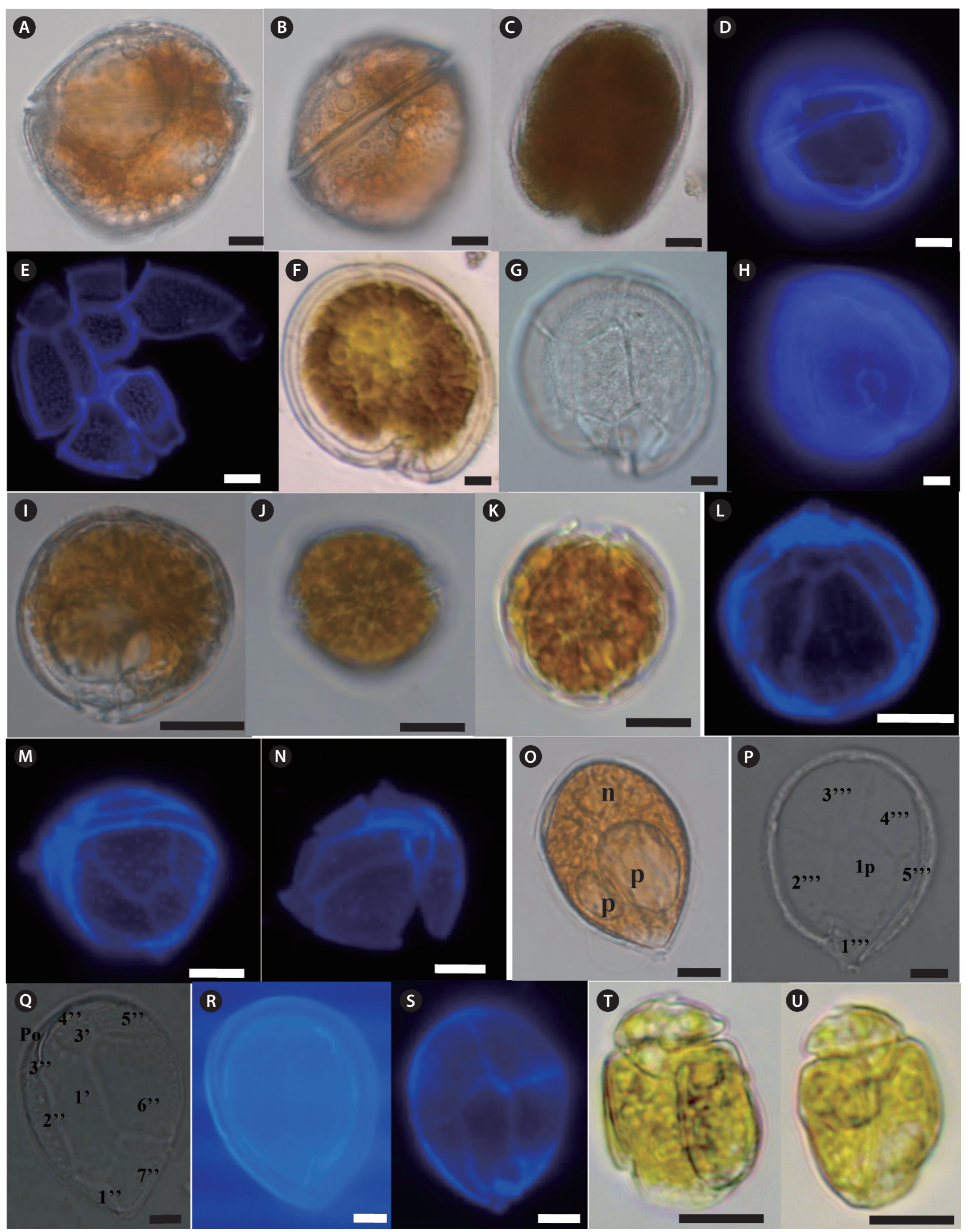

Fig. 3. Light micrographs of the genera Gambierdiscus, Coolia, Ostreopsis, and Amphidiniella (present study). A-E: Gambierdiscus yasumotoi, F-H: Gambierdiscus sp., I-N: Coolia malayensis, O-S: Ostreopsis ovata, T and U: Amphidiniella sp. Photos D, E, H, L, M, N, R, and S: epifluorescence. Scale bars, $10 \mu \mathrm{m}$. 


\section{Genus Amphidiniella Horiguchi 1995}

Amphidiniella sp. (Fig. 3T and 3U)

Reference: Murray 2003, p 83, fig. 2. 26, f-j, l, m.

Specimen examined: Slide LJB2012-17 at the NIBR, Incheon.

Description: Armored photosynthetic dinoflagellate with yellow-brown chloroplast, posterior nucleus, and central pyrenoid. Cell dorsoventrally flattened and oval from the ventral side. Epicone is small, asymmetric, deflected to the left and contain a hook-like projection. Hypocone is large with roundish posterior end. The cingulum is wide, left-handed. Sulcus is wide, with a prominent right ridge, reaches the antapex.

Size: $L(\mu \mathrm{m}): 22-30$ (25.1 \pm 0.8); W $(\mu \mathrm{m}): 18-25$ (19.8 \pm $0.7)$.

\section{Genus Amphidinium Claparède and Lachmann 1859}

\section{Amphidinium carterae Hulburt 1957 (Fig. 4A and 4B)}

Synonyms: Amphidinium microcephalum Norris 1961, Amphidinium klebsii Carter 1937.

References: Hulburt 1957, p 216, pl. 1: 1; Dodge 1982, p 69, fig. 7J; Larsen and Patterson 1990, p 889, fig. 47d; Murray and Patterson 2002, p. 284, figs. 11-15, 75; Flø Jørgensen et al. 2004b, p 353, fig. 1A; Murray et al. 2004, p 376, figs. 2F, 3E, 8A-F.

Description: Unarmored photosynthetic dinoflagellate with yellow-brown single chloroplast, posterior rounded nucleus, and central ring like starch sheathed pyrenoid. Cell is dorso-ventrally flattened and oblong to oval in ventral view. Eepicone is crescent shaped, deflected to the left, and minute compared to the hypocone. Line drawing of this species is shown in Fig. 4a (Murray and Patterson 2002).

Size: $L(\mu \mathrm{m}): 14.5-21.8$ (17.2 \pm 0.8); W $(\mu \mathrm{m}): 9.0-13.5$ $(11.8 \pm 0.7)$.

Harmful effects: Hemolysin compounds have been isolated from this species and ichthyotoxicity is known (Yasumoto et al. 1987).

Amphidinium gibbosum (Maranda and Shimizu 1996) Flø Jørgensen and Murray 2004 (Fig. 4C and 4D)

Basionym: Amphidinium operculatum var. gibbosum Maranda \& Shimizu.

Synonym: Amphidinium operculatum var. gibbosum Maranda \& Shimizu.

References: Maranda and Shimizu 1996, pp 873-879; Murray et al. 2004, p 373, figs. 2B, 3B, 5A-D.
Specimen examined: Slide LJB2012-01 at the NIBR, Incheon.

Description: Unarmored photosynthetic dinoflagellate with posterior rounded nucleus and large ring like pyrenoid located at the center of the hypocone. Cells are asymmetrical, ellipsoid, and dorsoventrally flattened. The hypocone is oval to heart shaped. The posterior part of the right side has a "hump-backed" appearance. Line drawing of this species is shown in Fig. 4b (Murray et al. 2004).

Size: $L(\mu \mathrm{m}): 28-38$ (32 \pm 0.55); W $(\mu \mathrm{m}): 17-22(19.8 \pm$ 0.6).

Harmful effects: Produces cytotoxic metabolites, the most potent showing antitumour activity (Maranda and Shimizu, 1996).

\section{Amphidinium herdmanii Kofoid and Swezy 1921 (Fig. 4E and F)}

Synonym: Amphidinium operculatum Herdman 1911

References: Lebour 1925, T. 2, p 23, fig. 2; Schiller 1933, p 294, fig. 238a-f; Dodge 1982, p 70, fig. 7H; Larsen 1985, p 21, figs. 20-25, 91; Murray and Patterson 2002, p 286, figs. 22-25, 79; Flø Jørgensen et al. 2004b: p 353, fig. 1C.

Specimen examined: Slide LJB2011-03 at the NIBR, Incheon.

Description: Unarmored photosynthetic dinoflagellate with posterior cresent shaped nucleus and pyrenoid like structure from where elongated chloroplast radiates. Cells are quadrangular-broadly oblong shape and dorsoventrally compressed. Epicone is triangular, slightly asymmetrical around the longitudinal axis, deflected toward the left. Hypocone is slightly asymmetrical with the left hand side being a little longer than the right. Line drawing of this species is shown in Fig. 4c (Murray and Patterson 2002).

Size: $L(\mu \mathrm{m}): 28-34(30 \pm 0.9) ; \mathrm{W}(\mu \mathrm{m}): 18-24(21.8 \pm 0.8)$.

Amphidinium incoloratum Campbell 1973 (Fig. 4G and 4H)

Synonym: Amphidinium klebsii Kofoid and Swezy 1921

References: Larsen and Patterson 1990, p 890, figs. 43cd, 44c; Murray and Patterson 2002, p 286, figs. 32-35, 80; Flø Jørgensen et al. 2004b, p 353, fig. 1B.

Specimen examined: Slide LJB2012-06 at the NIBR, Incheon.

Description: Unarmored nonphotosynthetic dinoflagellate with posterior rounded nucleus and colorless lipid globules or food particles in cytoplasm. Cells are broadly ellipsoidal to oval from the ventral side, with a relatively straight left side and a convex right side. The epicone is deflected to the left. The cingulum and sulcus are asym- 

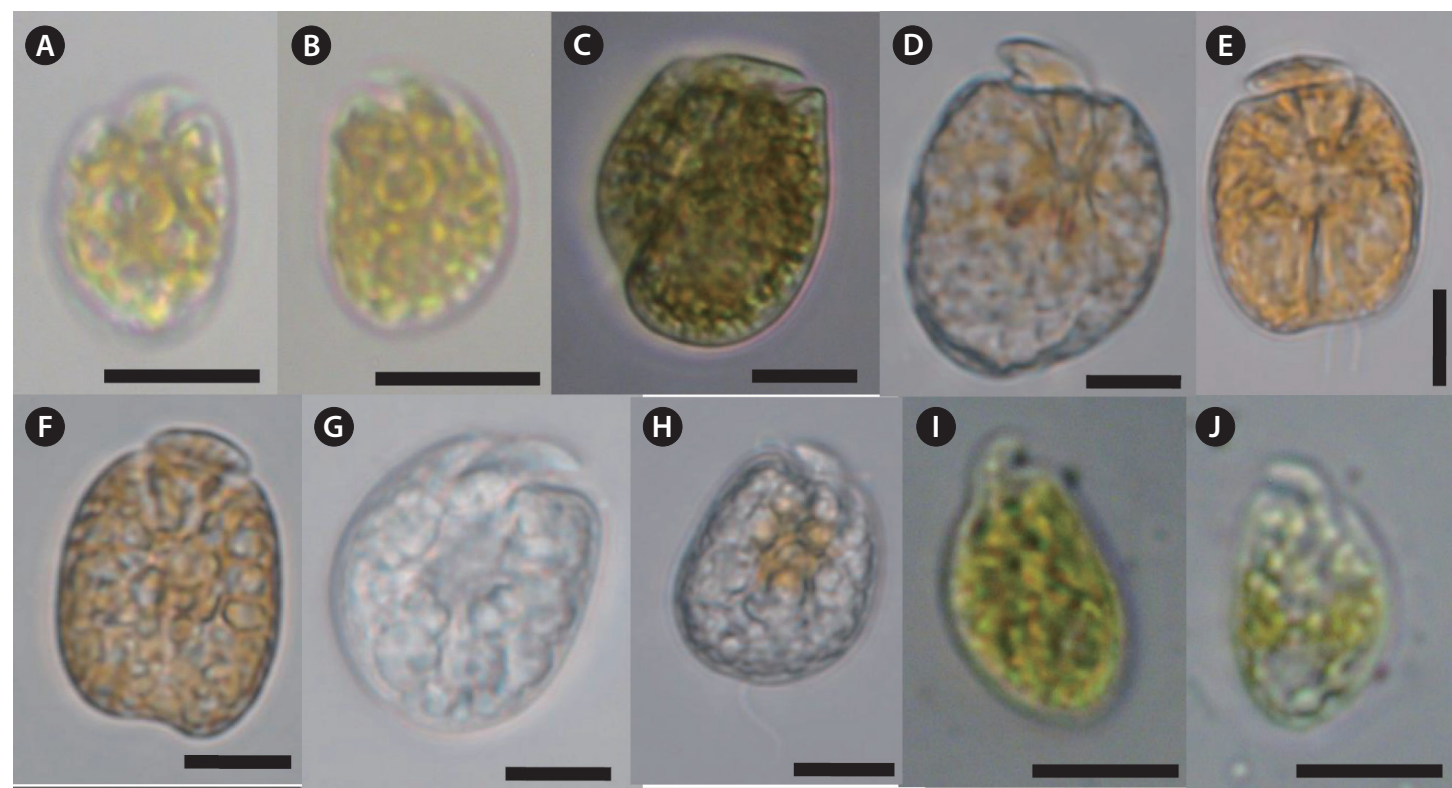

(G)

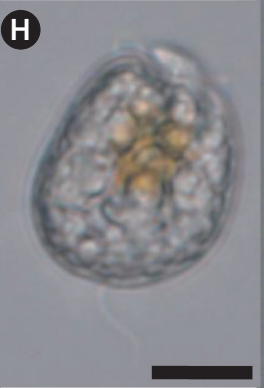

(I)

J
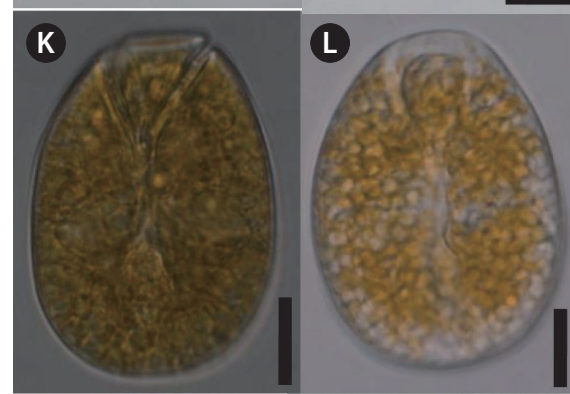

M
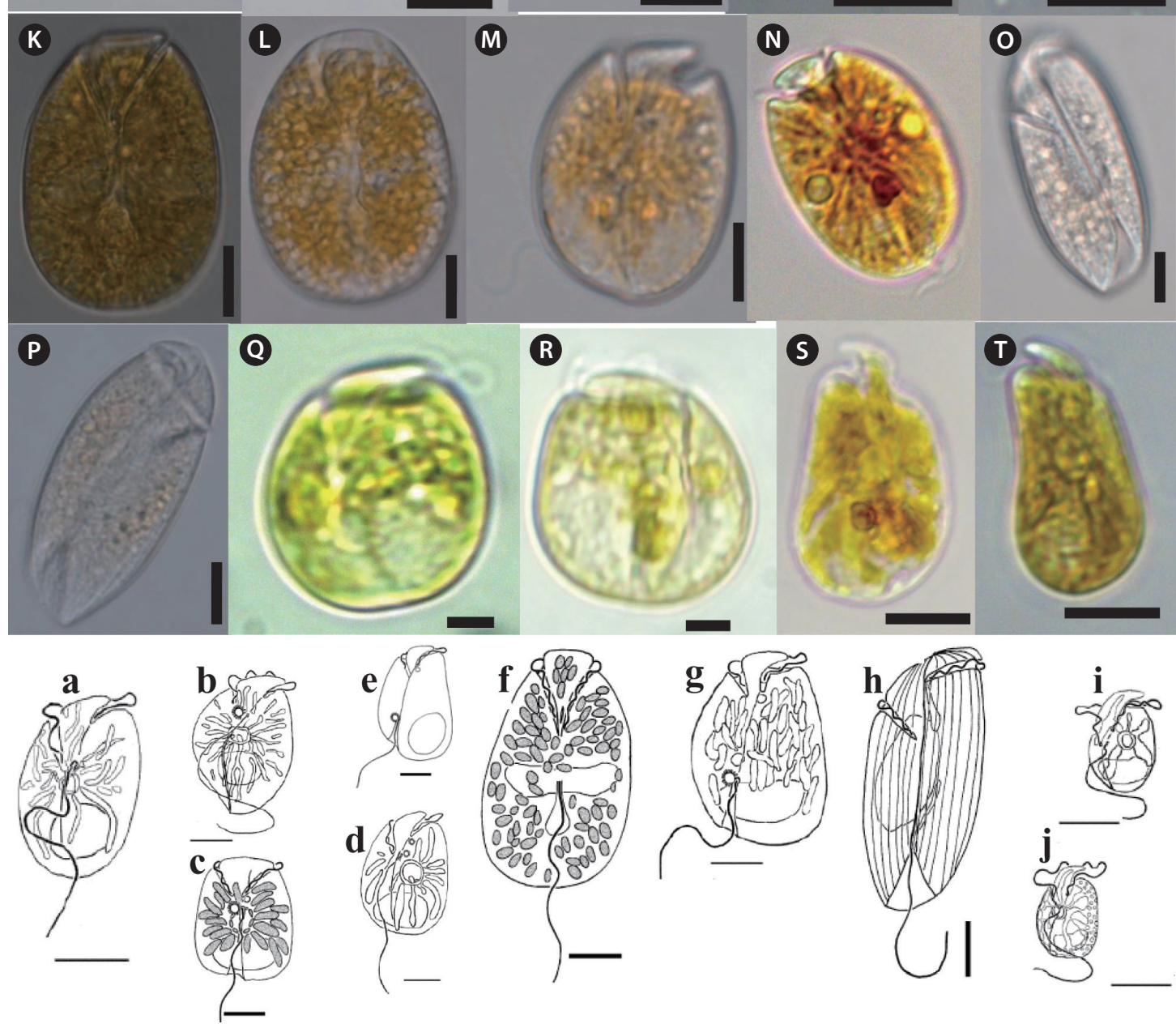

Fig. 4. Light micrographs of the genera Amphidinium (present study). A and B: Amphidinium carterae, $\mathrm{C}$ and D: Amphidinium gibbosum. E and F: Amphidinium herdmanii, $\mathrm{G}$ and $\mathrm{H}$ : Amphidinium incoloratum, I and J: Amphidinium massartii, $\mathrm{K}$ and $\mathrm{L}:$ Amphidinium mootonorum, $\mathrm{M}$ and $\mathrm{N}:$ Amphidinium operculatum, $\mathrm{O}$ and P: Amphidinium scissum, $\mathrm{Q}$ and R: Amphidinium steinii, $\mathrm{S}$ and T: Amphidinium trulla. (a-j): Line drawing of Amphidinium spp. (Murray and Patterson 2002, Murray et al. 2004): (a) Amphidinium carterae, (b) Amphidinium gibbosum, (c) Amphidinium herdmanii, (d) Amphidinium incoloratum, (e) Amphidinium massartii, (f) Amphidinium mootonorum, (g) Amphidinium operculatum, (h) Amphidinium scissum, (i) Amphidinium steinii, (j) Amphidinium trulla. Scale bars, $10 \mu \mathrm{m}$. 
metrical. The longitudinal flagellum arises in a pocket to the left and just below the start of the sulcus. Line drawing of this species is shown in Fig. 4d (Murray and Patterson 2002).

Size: $\mathrm{L}(\mu \mathrm{m}): 28-36(31.6 \pm 1.5) ; \mathrm{W}(\mu \mathrm{m}): 16-25(21 \pm 1.8)$.

\section{Amphidinium massartii Biecheler 1952 (Fig. 4I and 4J)}

Synonyms: Amphidinium hofleri Schiller and Diskus 1955

References: Biecheler 1952, p 24, figs 4, 5; Murray et al. 2004, p 375, figs. 2E, 3F, 7A-E; Lee et al. 2013, p 223, fig 6.

Specimen examined: Slide LJB2012-04 at the NIBR, Incheon.

Description: Unarmored photosynthetic dinoflagellate with rounded or crescent-shaped nucleus in the posterior part of the hypocone, central ringlike starch-sheathed pyrenoid. Cells are dorsoventrally flattened and oval from the ventral side. Single yellow-green plastid with several narrow lobes radiating out from the center of the cell. The epicone is minute, crescent shaped, and pointing toward the left. The hypocone is slightly pointed at the antapex. Line drawing of this species is shown in Fig. 4e (Murray et al. 2004).

Size: L $(\mu \mathrm{m}): 13-21$ (16.6 \pm 2.1$)$; $\mathrm{W}(\mu \mathrm{m}): 9-14.8(10.4 \pm$ $1.9)$.

Amphidinium mootonorum Murray and Patterson 2002 (Fig. 4K and 4L)

Reference: Murray and Patterson 2002, p 289, figs. 4042, 83.

Specimen examined: Slide LJB2011-04 at the NIBR, Incheon.

Description: Unarmored photosynthetic dinoflagellate with many small, yellow-brown chloroplasts and an elongate oval nucleus located in the center of the hypocone. Cells are dorsoventrally flattened and oval in ventral side. Epicone is "stem-shaped" at the junction of the cingulum and sulcus. Epicone slightly deflected towards the left. Cingulum is relatively wide. Sulcus narrow initially, opens into a teardrop-shaped indentation. Line drawing of this species is shown in Fig. $4 \mathrm{f}$ (Murray and Patterson 2002).

Size: L $(\mu \mathrm{m}): 38-52(44 \pm 2.4)$; W ( $\mu \mathrm{m})$ : 28-42 $(34.5 \pm 2.8)$.

\section{Amphidinium operculatum Claparède and Lachmann} 1859 (Fig. 4M and 4N)

Synonyms: Amphidinium elegans Grell and WohlfarthBottermann 1957, Amphidinium klebsii Kofoid and Swezy 1921, Amphidinium rhynchocephalum Anissimowa 1926, Amphidinium hofleri Schiller and Diskus 1955, Amphidinium wislouchi Hulburt 1957.
References: Claparède and Lachmann 1859, p 410, pl. 20: 9-10; Lebour 1925, T. 2, p 22, fig. 8a; Schiller 1933, p 304, fig. 304; Dodge 1982, p 73, fig. 7I; Flø Jørgensen et al. 2004b, p 358, fig. 2; Larsen and Nguyen 2004, p 119, pl. 22 : 2; Murray et al. 2004, p 368, figs. 1A-F, 2A, 3A.

Specimen examined: Slide LJB2012-03 at the NIBR, Incheon.

Description: Unarmored photosynthetic dinoflagellate with oval or crescent-shaped nucleus in the posterior part of the hypocone. The multiple plastids are yellow-brown and elongated, appearing to radiate to the cell periphery. Cell is ovoid to ellipsoidal and dorsoventrally flattened. The right side of the hypocone is convex but left is almost straight. A small epicone is irregularly triangular with the anterior left tip deflected to the left. The cingulum is displaced and slightly descending. The sulcus originates in the lower one-third of the cell. Line drawing of this species is shown in Fig. 4g (Murray et al. 2004).

Size: $\mathrm{L}(\mu \mathrm{m}): 20.3-48(33.6 \pm 2.5)$; $\mathrm{W}(\mu \mathrm{m}): 16-26.8$ (22.4 \pm 2.9 ).

Harmful effects: Compounds with hemolytic and antifungal properties (amphidinols) are reported, and they may be toxic to fish (Yasumoto et al. 1987).

\section{Amphidinium scissum Kofoid and Swezy 1921 (Fig. 40 and $4 \mathrm{P}$ )}

Synonym: Amphidinium scissoides Lebour 1925.

References: Kofoid and Swezy 1921, p 150, pl. 2: 22 U1; Dodge 1982, p 67, Fig. 6f; Murray and Patterson 2002, p 293, figs. 56-59, 87; Flø Jørgensen et al. 2004b, p 353, fig. 1J.

Specimen examined: Slide LJB2011-05 at the NIBR, Incheon.

Description: Unarmored non-photosynthetic dinoflagellate with ellipsoidal nucleus in the central-right side of the hypocone. Cells are elongate ellipsoidal to oblong from the ventral side, dorsoventrally flattened. The epicone is asymmetrical, and slopes down towards the right. The cingulum is relatively deep. The sulcus is narrow and shallow, reaches to the posterior end. Line drawing of this species is shown in Fig. 4h (Murray and Patterson 2002).

Size: $\mathrm{L}(\mu \mathrm{m})$ : 48-56 (50 \pm 0.6$)$; $\mathrm{W}(\mu \mathrm{m}): 20-24(21 \pm 0.4)$.

Amphidinium steinii Lemmermann 1910 (Fig. 4Q and 4R)

Synonyms: Amphidinium rostratum Proskina-Lavrenko 1945, Amphidinium wislouchi Hulburt 1957.

References: Lebour 1925, T. 2, p 23, fig. 8b; Schiller 1933, p 316, figs. 310a, b; Murray et al. 2004, p 371, figs. 2C, 3D, 4A-J. 
Specimen examined: Slide LJB2012-02 at the NIBR, Incheon.

Description: Unarmored phototrophic dinoflagellate with round to oval nucleus in the posterior part of the hypocone, single yellow-brown plastid and the ringlike starch-sheathed pyrenoid. Cells are oval from the ventral side and dorsoventrally flattened. The epicone is minute, triangular, curved anteriorly, and clearly deflected to the left. The sulcus begins just to the right of the mid-ventral line. Two small pusules are present, one below the origin of the cingulum and the other to the right of the origin of the sulcus. Line drawing of this species is shown in Fig. $4 \mathrm{i}$ (Murray et al. 2004).

Size: L $(\mu \mathrm{m}): 25.3-32.7(28.5 \pm 1.0)$; W $(\mu \mathrm{m})$ : 18-24 (20.4 \pm 0.9 ).

Amphidinium trulla Murray, Rhodes et Flø Jø rgensen 2004 (Fig. 4S and 4T)

References: Murray et al. 2004, p 374, figs. 2D, 3C, 6A-D.

Specimen examined: Slide LJB2012-05 at the NIBR, Incheon.

Description: Unarmored non-photosynthetic dinoflagellate with ellipsoidal nucleus in the central-right side of the hypocone, yellow-brown plastid, and central pyrenoid. Cells are oval from the ventral side and dorsoventrally flattened. The minute crescent-shaped epicone overlays the anterior part of the hypocone. The epicone is anteriorly curved rather than flat and slopes to the right. Line drawing of this species is shown in Fig. 4j (Murray and Patterson 2002).

Size: L ( $\mu \mathrm{m})$ : $18-31(26.5 \pm 2.7)$; $\mathrm{W}(\mu \mathrm{m}): 13-24$ (14.9 \pm 2.5).

\section{Genus Testudodinium (Larsen and Patterson) Horiguchi, Tamura, et Yamaguchi 2012}

\section{Testudodinium corrugatum (Larsen and Patterson)} Horiguchi, Tamura, et Yamaguchi 2012 (Fig. 5A-5C)

Basyonym: Amphidinium corrugatum Larsen and Patterson 1990 .

References: Larsen and Patterson 1990, p 889, figs. 44a, 45a, b; Murray and Patterson 2002, p 284, figs. 16-18, 76, 77; Horiguchi et al. 2012, pp 143-145, figs 18-31.

Specimen examined: Slide LJB2011-02 at the NIBR, Incheon.

Description: Unarmored photosynthetic dinoflagellate with yellow-brown chloroplasts and oval to crescent-shaped posterior nucleus. Cells are dorsoventrally flattened and oval from the ventral side. Longitudinal flagellum originates from just below the pusule. Epicone small, club-shaped, hypocone forms a "collar" around the epicone. Line drawing of this species is shown in Fig. 5A (Murray and Patterson 2004).

Size: $\mathrm{L}(\mu \mathrm{m})$ : $26-32(28.2 \pm 0.8)$; $\mathrm{W}(\mu \mathrm{m})$ : $21-28(24 \pm 0.7)$.

\section{Genus Gyrodinium Kofoid and Swezy 1921}

Gyrodinium instriatum Freudenthal and Lee 1963 (Fig. 5D-5F)

References: Freudenthal and Lee 1963, figs. 15-17; Steidinger and Tangen 1997, p 450, pl. 1, 19.

Specimen examined: Slide LJB2012-03 at the NIBR, Incheon.

Description: Unarmored photosynthetic dinoflagellate with large elliptical nucleus in the epicone. Cells are ovoid and slightly dorsoventrally compressed. Epicone tapering gently toward truncate apex in ventral and dorsal views. Hypocone is slightly longer and wider, slightly more truncate at antapex, more trapezoidal in side view. Cingulum is narrow. Sulcus is invading spherical region of the epicone and extending posteriorly to the antapex. Line drawing of this species is shown in Fig. 5D (Freudenthal and Lee 1963).

Size: L $(\mu \mathrm{m}):$ 48-68 (56.2 \pm 3.5$)$; W $(\mu \mathrm{m}):$ 32-56 (44.9 \pm 2.5).

\section{Genus Gymnodinium Claparède and Lachmann 1859}

Gymnodinium venator Flø Jørgensen and Murray 2004 (Fig. 5G-5I)

Basionym: Amphidinium pellucidum C. Herdman, 1922.

Synonym: Amphidinium subsalsum Biecheler, 1952.

References: Herdman 1922, pp 27-28, pl. 1: 7; Dodge 1982, p 67, fig. 6G; Murray and Patterson 2002, p 291, figs. 47-51, 85; Flø Jørgensen et al. 2004b, p 353, fig. 1H; Flø Jørgensen et al. 2004b, p 1181.

Specimen examined: Slide LJB2012-08 at the NIBR, Incheon.

Description: Unarmored non-photosynthetic dinoflagellate with crescent-shaped nucleus in the upper part of the cell, and colored bodies in the posterior end of the hypocone. Cell is oblong shape, dorsoventrally flattened. Epicone is obtuse, hypocone broadly sack-shaped. Cingulum is wide, incised, tapering distally, descending in a left turning spiral, slightly displaced. Sulcus extends onto the epicone reaching the apex to produce a small notch, acute on the epicone. Line drawing of this species is shown in Fig. 5G (Murray and Patterson 2004). 

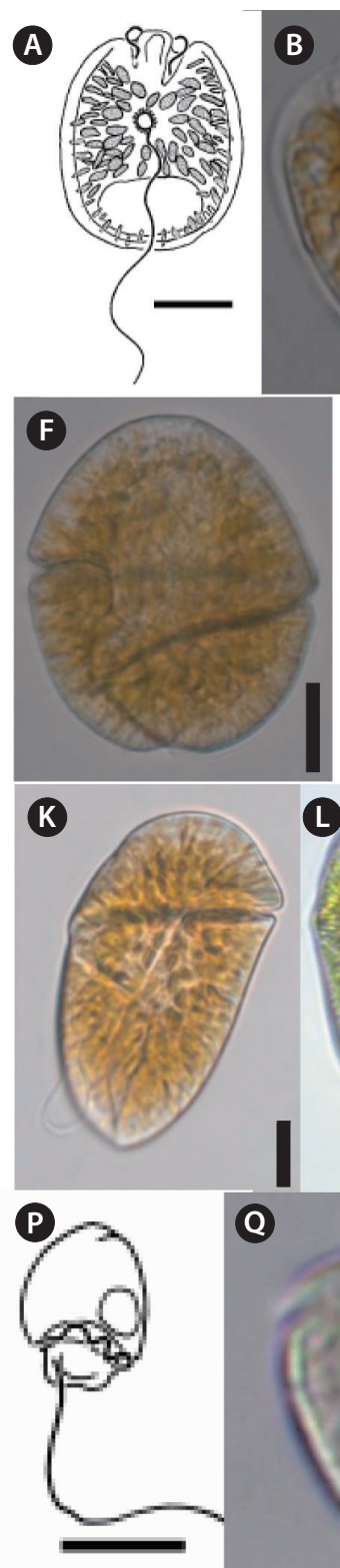

Q
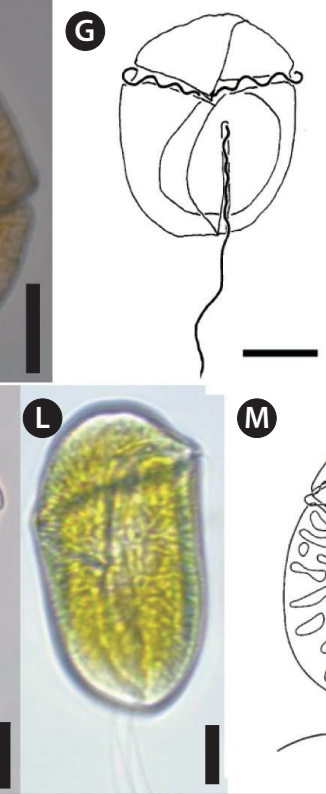

M

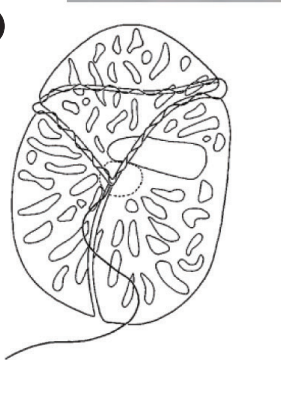

R
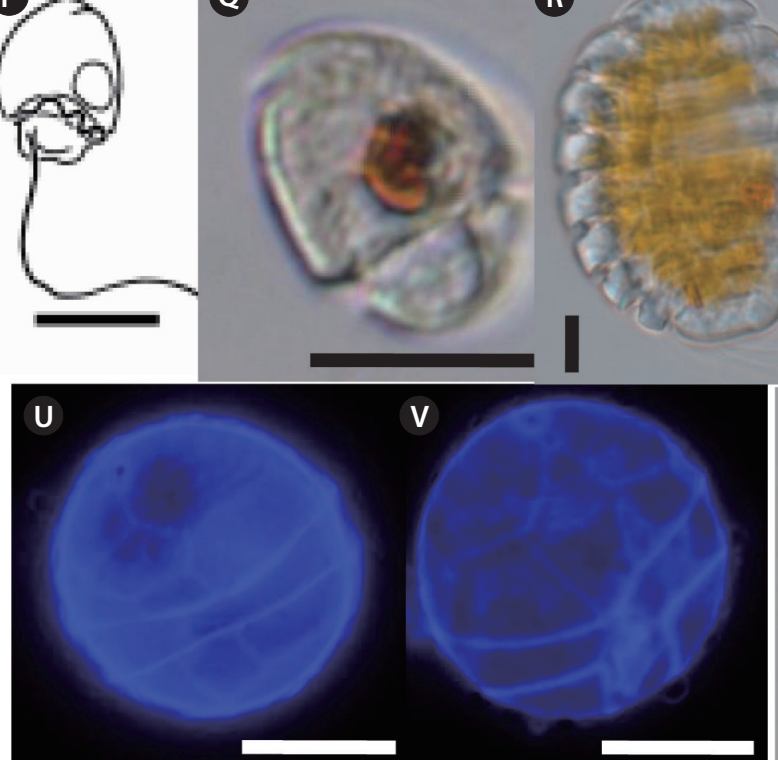
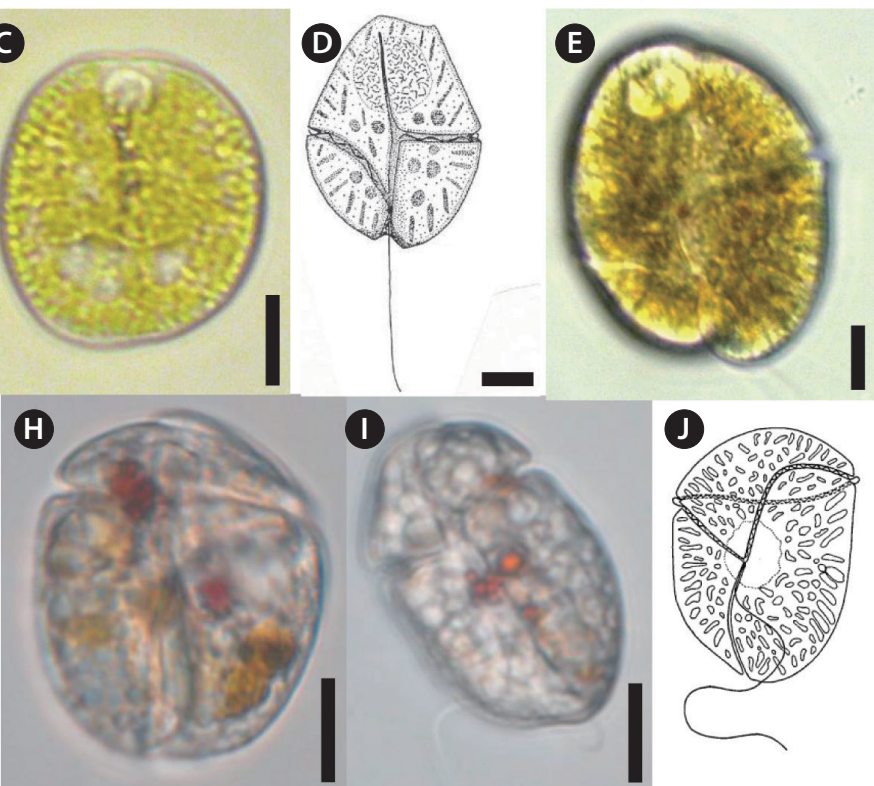

N

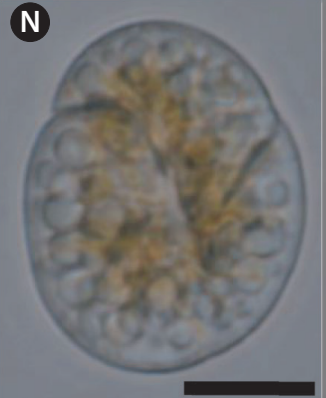

0
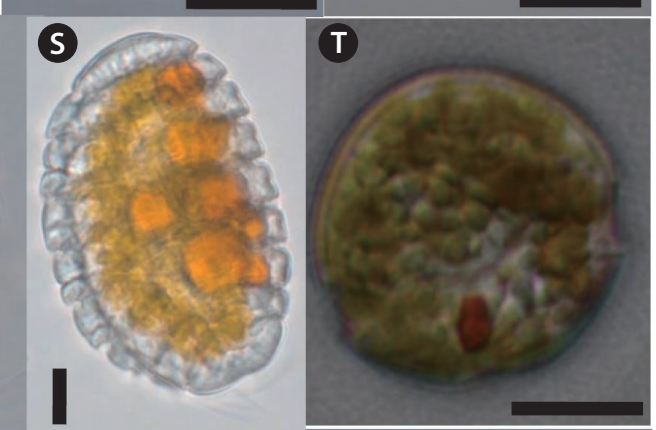

W

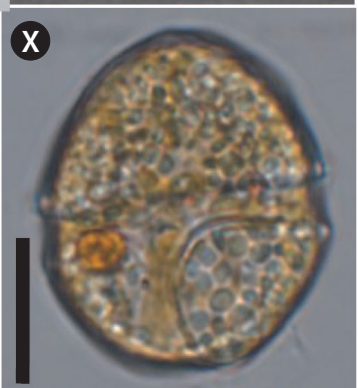

Fig. 5. Light micrographs of the genera Testudodinium, Gyrodinium, Gymnodinium, Togula, Katodinium, Polykrikos, and Durinskia. A: Line drawing of Amphidinium corrugatum (Murray and Patterson 2002), B and C: Testudodinium corrugatum (present study), D: Line drawing of Gyrodinium instriatum (Freudenthal \& Lee 1963), E and F: Gyrodinium instriatum (present study), G: Line drawing of Amphidinium pellucidum (Murray and Patterson 2002), H and I: Gymnodinium venator (present study), J: Line drawing of Togula Britannica (Flø Jørgensen et al. 2004a), K and L: Togula Britannica (present study), M: Line drawing of Togula jolla (Flø Jørgensen et al. 2004a), N and O: Togula jolla (present study), P: Line drawing of Katodinium asymmetricum (Al-Qassab et al. 2002), Q: Katodinium asymmetricum (present study), R and S: Polykrikos lebourae, T-V: Durinskia baltica, W and X: Durinskia capensis (present study). Epifluorescence photos: U, V. Scale bars, $10 \mu \mathrm{m}$. 
Size: L $(\mu \mathrm{m}): 28-39$ (36.8 \pm 0.9); W $(\mu \mathrm{m}): 25-32.5(29.0$ \pm 0.8 ).

\section{Genus Togula Flø Jørgensen, Murray et Daugb- jerg 2004}

Togula britannica (Herdman 1922) Flø Jørgensen, Murray et Daugbjerg 2004 (Fig. 5J-5L)

Basionym: Amphidinium asymmetricum var. britannicum Herdman 1922.

References: Herdman 1922, p 18, fig. 5; Lebour 1925, p 22, fig. 8a; Dodge 1982, p 68, fig. 7E; Larsen 1985, p 20, figs. 14-19, 90; Flø Jørgensen et al. 2004a, pp 289-291, figs. 2-12, 36 .

Specimen examined: Slide LJB2011-07 at the NIBR, Incheon.

Description: Unarmored non-photosynthetic dinoflagellate with nucleus in the center of the cell, and irregular golden-brown chloroplasts. Cell is elongate ellipsoidal, dorsoventrally flattened. The longitudinal flagellum length is almost the same as the cell length. The cingulum is highly asymmetrical. In ventral view, the proximal end originates slightly right of the center of the cell and has a straight longitudinal to left course towards the apex. Line drawing of this species is shown in Fig. 5J (Flø Jørgensen et al. 2004a).

Size: L ( $\mu \mathrm{m})$ : 40-68 (50.2 \pm 3.2$)$; $\mathrm{W}(\mu \mathrm{m}): 30-40(34.8 \pm$ 2.6).

Togula jolla Flø Jørgensen, Murray et Daugbjerg 2004 (Fig. 5M-50)

References: Flø Jørgensen et al. 2004a, pp 295-295, figs. 22-35.

Specimen examined: Slide LJB2012-09 at the NIBR, Incheon.

Description: Cells dorso-ventrally flattened. Cingulum originated just below the cell center, with an anterior-left course before turning left and descending in a sigmoid shape dorsally. Cingulum displacement is approximately 0.5 times the cell length. Numerous irregular elongated chloroplasts present radiating from the center towards the periphery. Nucleus is oval and located in the mid-ventral plane. Line drawing of this species is shown in Fig. 5M (Flø Jørgensen et al. 2004a).

Size: $\mathrm{L}(\mu \mathrm{m})$ : $24-40$ (32.4 \pm 3.9$)$; W $(\mu \mathrm{m}): 20-33$ (26.0 \pm 2.8).

\section{Genus Katodinium Fott 1957}

Katodinium asymmetricum (Massart 1920) Loeblich
1965 (Fig. 5P and 5Q)

Synonyms: Gymnodinium asymmetricum Massart 1900, Massartia asymmetrica (Massart) Schiller 1933, Massartia asymmetrica Carter 1937.

References: Loeblich 1965, p 16; Dodge 1982, p 127, fig. 15D; Larsen and Patterson 1990, p 895, fig. 44f; Al-Qassab et al. 2002, p 118, fig.12p.

Specimen examined: Slide LJB2011-06 at the NIBR, Incheon.

Description: Armored non-photosynthetic dinoflagellate. Cell is oblong and dorsoventrally flattened. Epicone dome-shaped and its length is about two-thirds of the total cell length. The outline of the epicone is broken by a small incision a little to the left of the mid-ventral line. Hypocone is narrower than the epicone. Line drawing of this species is shown in Fig. 5P (Al-Qassab et al. 2002).

Size: L $(\mu \mathrm{m}): 11-18(14 \pm 0.5)$; $\mathrm{W}(\mu \mathrm{m}): 8-12(10 \pm 0.2)$.

\section{Genus Polykrikos Butschli 1873}

Polykrikos lebourae Herdman 1923 emend. Hoppenrath et Leander 2007(Fig. 5R and 5S)

Reference: Hoppenrath and Leander 2007, p 370, fig.1e,lf.

Specimen examined: Slide LJB2012-16 at the NIBR, Incheon.

Description: Unarmored non-photosynthetic dinoflagellate with pseudocolonies consisting of eight zooids, eight sets of longitudinal and transverse flagella, and two nuclei; small, golden-brown, spherical, or spindle-shaped plastids with central pyrenoid. Pseudocolonies are oval shape and obliquely flattened. Loop-shaped acrobase presents. Sometimes the cell contains food bodies. Fused sulci and cinguli descending displaced about one to two cingular widths.

Size: L ( $\mu \mathrm{m})$ : 40-84.5 (58.2 \pm 3.9$)$; W ( $\mu \mathrm{m}):$ 20-56 (37.8 \pm 2.8 .

\section{Genus Durinskia Carty and Cox 1986}

\section{Durinskia baltica Carty and Cox 1986 (Fig. 5T-5V)}

Reference: Carty and Cox 1986, p 200, figs. 7, 8, 9b, 10b, $11-14$.

Specimen examined: Slide LJB2011-12 at the NIBR, Incheon.

Description: Armored photosynthetic dinoflagellate with numerous golden-brown chloroplasts. Cells round to ovoid, slightly dorsi-ventraly flattened, small in size. Epitheca is slightly larger than hypotheca. Cingulum well excavated, left handed, and displaced; sulcus conspicu- 
ous. A conspicuous, bright red, large, and rectangular eyespot is located on the left part of sulcus. The thecal plate formula is Po, $\mathrm{x}, 4$, 2a, 6", 5c, 4s, 5"', 2"'.

Size: $\mathrm{L}(\mu \mathrm{m}): 16-28(20.2 \pm 2.4)$; $\mathrm{W}(\mu \mathrm{m}): 15.8-25$ (18.8 $\pm 2.8)$.

\section{Durinskia capensis Pienaar, Sakai et Horiguchi 2007 (Fig. $5 \mathrm{~W}$ and $5 \mathrm{X}$ )}

Reference: Pienaar et al. 2007, pp 249-253, figs. 1-7.

Specimen examined: Slide LJB2011-13 at the NIBR, Incheon.

Description: Armored photosynthetic dinoflagellate. Cell rounded to ovoidal and dorsoventrally flattened. Hemispherical epitheca is slightly larger than the hemispherical trapezoidal hypotheca. Cingulum well excavated, left-handed. Sulcus is conspicuous. The hook-shaped eyespot is conspicuous, bright red, and located on left side of the upper part of the sulcus.

Size: L $(\mu \mathrm{m}): 22-28$ (24.5 \pm 0.3); W $(\mu \mathrm{m}): 18-25$ (22.8 \pm $0.8)$.

\section{Genus Heterocapsa Stein 1883}

Heterocapsa psammophilla Tamura, Iwataki et Horiguchi 2005 (Fig. 6A-6D)

Reference: Tamura et al. 2005, pp 304-309, figs. 1-20.

Specimen examined: Slide LJB2012-08 at the NIBR, Incheon.

Description: Armored photosynthetic dinoflagellate with yellow-brown chloroplasts, spherical pyrenoid, and spherical nucleus situated in the hypotheca. Cells are ovoidal; almost equally sized epitheca (bell-shaped) and hypotheca (bowl shape). Width of the cingulum is approximately one-eighth to one-tenth the cell length and is displaced by almost half its width. Line drawing of this species is shown in Fig. 6A (Iwataki 2008).

Size: $\mathrm{L}(\mu \mathrm{m}): 17-22(21.5 \pm 0.3)$; $\mathrm{W}(\mu \mathrm{m}): 12-18$ (17.8 \pm $0.6)$.

\section{Genus Amphidiniopsis Woloszyńska 1929}

Amphidiniopsis swedmarkii (Balech 1956) Dodge 1982 (Fig. 6E-6H)

Basionym: Thecadinium swedmarkii Balech 1956

References: Dodge 1982, p 248, fig. 33D, 33E; Hoppenrath 2000b, p 483, figs. 4, 5, 19, 34-45.

Specimen examined: Slide LJB2011-17 at the NIBR, Incheon.

Description: Armored non photosynthetic dinoflagellate. Cells are rectangular, rounded posteriorly, dor- soventrally flattened. The cytoplasm contains colorless granules. Epitheca is cap-like and slightly narrow than the hypotheca. There are two large antapical spines. Two pusules lie in the lower right and upper left lateral part of the hypocone. The cingular and sulcal plates are smooth with scattered pores. Line drawing of this species is shown in Fig. 6E (Hoppenrath 2000b).

Size: L $(\mu \mathrm{m})$ : 48.5-52.8 (51.2 \pm 2.4$)$; W $(\mu \mathrm{m}): 38-44.5$ $(42.1 \pm 1.8)$.

Amphidiniopsis rotundata Hoppenrath and Selina 2012 (Fig. 6I-6L)

Reference: Hoppenrath et al. 2012, pp 155-167, figs. $1-21$.

Specimen examined: Slide LJB2011-18 at the NIBR, Incheon.

Description: Armored nonphotosynthetic dinoflagellate. Cells rounded, dorsoventrally flattened. The smaller cap-like epitheca is slightly narrower than the hypotheca. The cingulum is slightly ascending about half of the cingular width. Sulcus distinctively curved and shifted to the left of the ventral side of the cell. One or two pusules are visible in living cells. Cells are colorless, and no food particles observed. Line drawing of this species is shown in Fig. 6I (Hoppenrath et al. 2012).

Size: L ( $\mu \mathrm{m})$ : 22.5-36.8 (26.2 \pm 1.4$)$; W ( $\mu \mathrm{m}): 21-34.5$ $(31.1 \pm 0.8)$.

\section{Genus Thecadinium Schiller 1933}

Thecadinium kofoidii (Herdman) Schiller 1933 (Fig. 6M-60)

Synonyms: Amphidinium kofoidi var. petasatum Herdman 1922, Thecadinium petasatum Kofoid and Skogsberg 1928, Thecadinium petasatum Dodge 1982.

Reference: Steidinger and Tangen 1997, p 548, pl. 55A-B.

Specimen examined: Slide LJB2011-19 at the NIBR, Incheon.

Description: Armored photosynthetic dinoflagellate. Cells are oval and laterally compressed. Cingulum not displaced or may be slightly displaced. Nucleus is oval in the posterior part of the hypocone. Chloroplast appears to be single, radiating from the center of the cell.

Size of specimen: $L(\mu \mathrm{m}): 20-35(24.6 \pm 2.5)$; $W(\mu \mathrm{m})$ : $18-32(22.8 \pm 2.3)$.

Thecadinium yashimaense Yoshimatsu, Toriumi et Dodge 2004 (Fig. 6P-6R)

Synonyms: Thecadinium mucosum Hoppenrath and Taylor 2004, Thecadinium foveolatum Bolch 2004. 

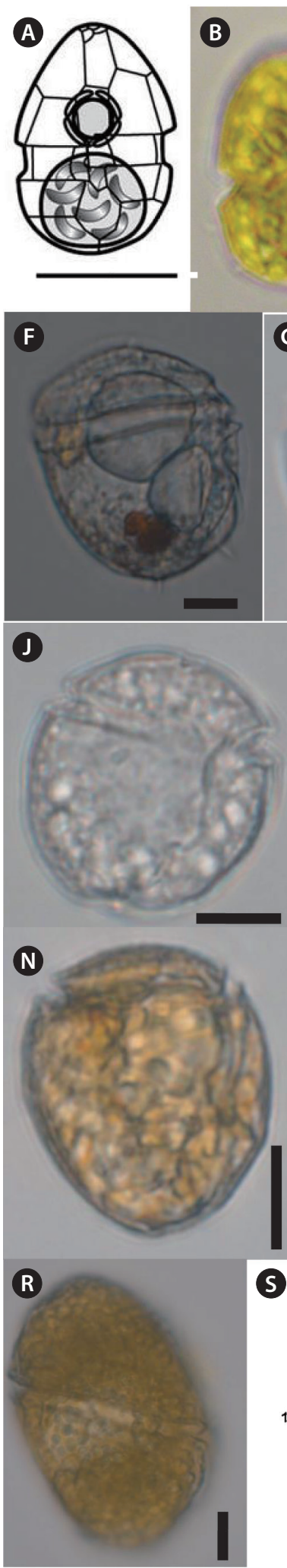
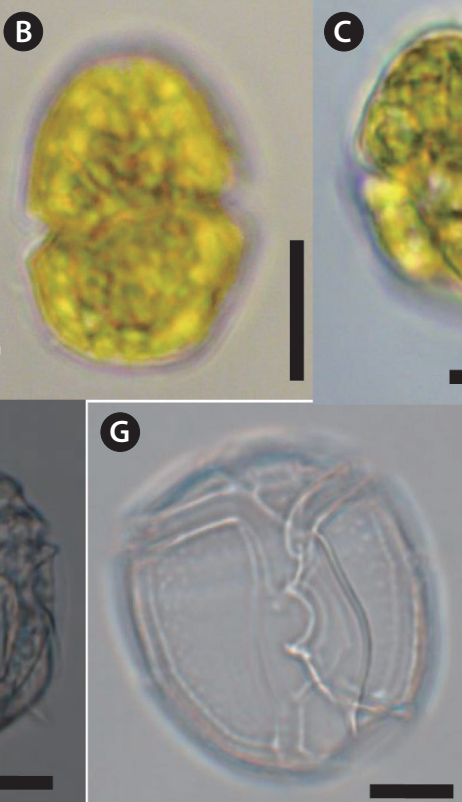

\section{๔}

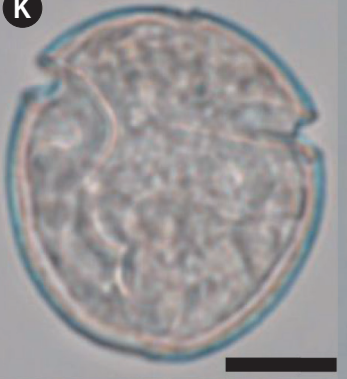

o

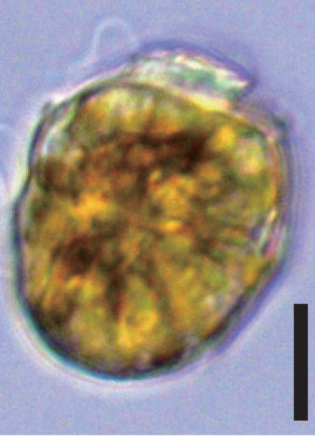

(H)

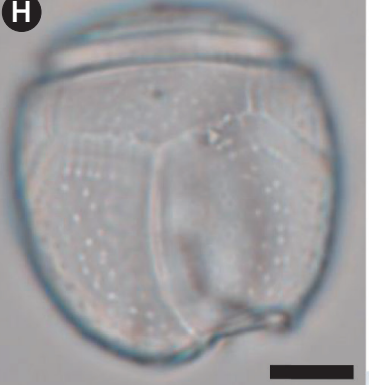

L

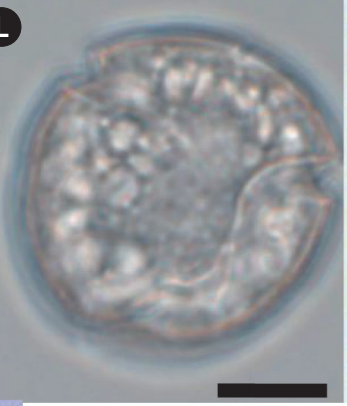

P

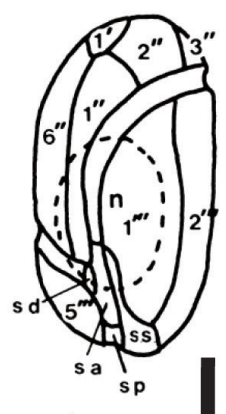

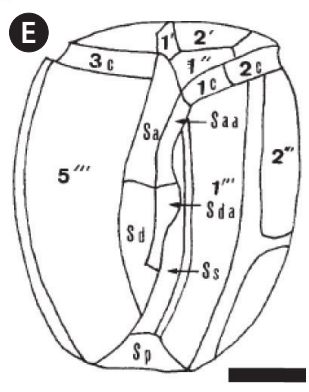

(1)

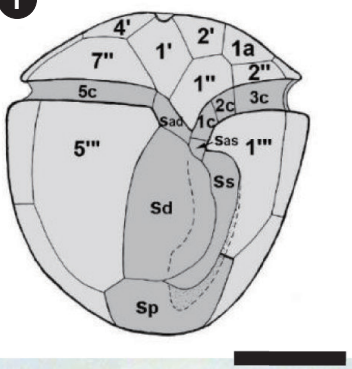

(11)
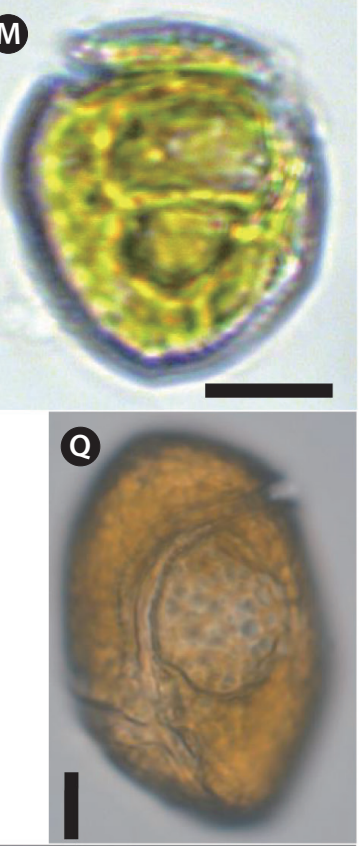

(U)

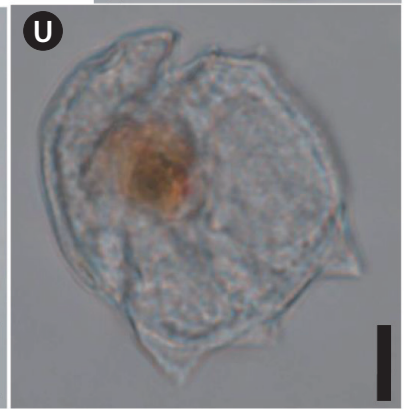

Fig. 6. Light micrographs of the genera Heterocapsa, Amphidiniopsis, Thecadinium, and Cabra. A: Line drawing of Heterocapsa psammophilla (Iwataki 2008), B-D: Heterocapsa psammophilla (present study), E: Line drawing of Amphidiniopsis swedmarkii (Hoppenrath 2000b), F-H: Amphidiniopsis swedmarkii (present study), I: Line drawing of Amphidiniopsis rotundata (Hoppenrath et al. 2012), J-L: Amphidiniopsis rotundata (present study), M-O Thecadinium kofoidii (present study), P: Line drawing of Thecadinium yashimaense (Yoshimatsu et al. 2004), Q and R: Thecadinium yashimaense (present study), S: Line drawing of Cabra matta (Murray and Patterson 2004), T and U: Cabra matta (present study), Scale bars, $10 \mu \mathrm{m}$. 
Reference: Yoshimatsu et al. 2004, p 216, figs 5, 31-38, 50. Specimen examined: Slide LJB20110-20 at the NIBR, Incheon.

Description: Armored dinoflagellate with colorless cytoplasm, greenish food vacuoles. Cell dorsoventrally flattened, shape highly variable Chilodonella-like, with rather conspicuous rostrum anteriorly left of oral opening and posteriorly, producing a more or less distinct sigmoidal outline. Nuclear apparatus in middle third of cell, on average subequatorial, anchored to the cortex by a fibrous basket with long extensions, a unique property within the class. Line drawing of this species is shown in Fig. 6P (Yoshimatsu et al. 2004).

Size: L ( $\mu \mathrm{m})$ : 40-65 (51.6 \pm 3.3); W ( $\mu \mathrm{m})$ : 24-38 (30.8 \pm 3.25).

\section{Genus Cabra Murray and Patterson 2004}

\section{Cabra matta Murray and Patterson 2004 (Fig. 6S and 6U)}

Reference: Murray and Patterson 2004, p 230, figs 1-18. Specimen examined: Slide LJB2011-14 at the NIBR, Incheon.

Description: Armored non photosynthetic dinoflagellate. Cells are oval to rectangular and irregular and strongly laterally compressed. Flat hypotheca is much larger than the epitheca. Cell surface is areolate with many indentations and small pores. Cingulum is strongly ascending and incompletely encircles the cell. A large red body or food body is present. Line drawing of this species is shown in Fig. 6S (Murray and Patterson 2004).

Size of specimen: $L(\mu \mathrm{m}): 32-42(34.5 \pm 2.3)$; $\mathrm{W}(\mu \mathrm{m})$ : $22-32(28.8 \pm 2.8)$.

\section{DISCUSSION}

Eighteen genera including 37 species of benthic dinoflagellates were identified during this study. The number of idenfied species is comparatively higher than previously published studies, such as Fukuyo (1981) (11 species), Turquet et al. (1998) (12 genera, 39 species), Parsons and Preskitt (2007) (26 species), Mohammad-Noor et al. (2007) (9 genera and 24 species), Selina and Levchenko (2011) (8 genera, 13 species, including five potentially toxic species), and Kim et al. (2011) (five genera, five species). This suggests that Jeju Island's coastal waters contain diversified benthic dinoflagellate flora.

In our study, we identified 31 benthic dinoflagellates as new records for Jeju Island and Korean waters. These newly recorded species are previously unreported in the study area and have not been formally reported in scientific journals or monographs. Morphological observations of the benthic dinoflagellates from this study generally agreed with previous taxonomic descriptions from other geographical locations. The list of the species found in this study will add to the existing record on marine benthic dinoflagellates in Jeju coastal waters and can be used for future reference in phytoplankton studies.

The number of marine sand-dwelling dinoflagellates in the present study was less compared to studies by Carlson (1984) (46 species), Hoppenrath et al. (2003) (28 genera, 140 species), Murray (2003) (56 species), and Saburova et al. (2009) (43 taxa). However the total number from the present study was higher than that reported by Faust $(1996,2009)$. The differences in the number of sand-dwelling dinoflagellates could be attributed to several factors such as variation or uniqueness of the sampling station, period, or type of sediment. Sampling strategies (collection methods, seasonal distribution of species, sampling duration, etc) could also be responsible for the variation in the number of species identified (Hoppenrath and Elbrächter 1998). In addition, the presence of dinoflagellates is less in sediment compared to in the water column (Anderson and Kawachi 2005). It has also been reported that species richness in benthic and epiphytic dinoflagellate assemblages is usually lower than that of planktonic species (Okolodkov et al. 2007). Sand is a preferred habitat for benthic dinoflagellate species including surface macroalgae, algal turf, and detritus (Bagnis et al. 1985, Morton and Faust 1997, Aligizaki and Nikolaidis 2008). Fenchel (1988) reported that the inshore sand at South Water Cay provides an ideal habitat where benthic dinoflagellates divide among sand grains and proliferate in the nutrientenriched benthic environment. It is also known that dinoflagellates seek shelter from meiofaunal predators (Faust 1996) in the interstitial spaces between sand grains. Faust (1990) reported the association between sand grains and biodetritus, benthic debris, and mangrove detritus. Furthermore, dinoflagellates are particle-associated forms that attach loosely to sand grains (Faust 1996). The presence of a number of sand dwelling benthic dinoflagellates suggests that the intertidal zones of Jeju Island coast are serving as potential nurseries or a seed-bank for dinoflagellates.

The presence of nine potentially toxic species, known to be causative of ciguatera fish poisoning viz. Amphidinium, Gambierdiscus, Ostreopsis, and Prorocentrum, and mainly dominated by species such as Amphidinium carterae, A. operculatum, and O. ovata at all sampling stations, indicates a potential risk (such as ciguatera fish 
poisoning) posed by these benthic dinoflagellates on Jeju Island. Hence, these potentially toxic benthic dinoflagellates in Jeju Island waters must be viewed as a threat to seafood safety and thus will have major socioeconomic repercussions. Furthermore, monitoring marine biotoxins with respect to marine edible organisms, such as fish and cephalopods, is mandatory.

The existence of subtropical/tropical benthic dinoflagellates on Jeju Island is reflective of the changing climate from temperate to subtropical. We believe that the occurrence and distribution of tropical species highly reflects the flow pattern of the Tsushima Warm Current, which is affecting distribution more strongly than in the past, courtesy of the changing climate.

In conclusion, the results of this study have added to the existing dinoflagellate taxa including a large number of unrecorded and several potentially toxic species from sand sediment and macroalgae in the intertidal zone along the coasts of Jeju Island. Future studies should be carried out on the detailed taxonomy, molecular phylogeny, and seasonal abundance of benthic dinoflagellates to provide detailed information on the benthic dinoflagellates of Jeju Island.

\section{ACKNOWLEDGMENTS}

This work was supported by a grant from National Institute of Biological Resources (NIBR), funded by the Ministry of Environment, Korea (NIBR No. 2013-01-001), and by the research grant of Jeju National University in 2012 to Md. M. R. Shah, and partly by Jeju Sea Grant in 2012, funded by the Ministry of Ocean and Fisheries (MOF) of the Republic of Korea.

\section{LITERATURE CITED}

Aligizaki K, Nikolaidis G. 2006. The presence of the potentially toxic genera Ostreopsis and Coolia (Dinophyceae) in the North Aegean Sea, Greece. Harmful Algae 5: 717730.

Aligizaki K, Nikolaidis G. 2008. Morphological identification of two tropical dinoflagellates of the genera Gambierdiscus and Sinophysis in the Mediterranean Sea. J Biol Res-Thessalon 9: 75-82.

Aligizaki K, Nikolaidis G, Fraga S. 2008. Is Gambierdiscus expanding to new areas? Harmful Algae News 36: 6-7.

Al-Qassab S, Lee WJ, Murray S, Simpson AGB, Patterson DJ. 2002. Flagellates from stromatolites and surrounding sediments in Shark Bay, Western Australia. Acta Protozool 41: 91-144.

Al-Yamani FY, Saburova MA. 2010. Illustrated Guide on the Flagellates of Kuwait's Intertidal Soft Sediments. Kuwait Institute for Scientific Research, Safat.

Andersen RA, Kawachi M. 2005. Traditional microalgae isolation techniques. In: Algal Culturing Techniques (Andersen RA, ed). Elsevier Academic Press, San Diego, CA, pp 83-101.

Bagnis R, Bennett J, Prieur C, Legrand AM. 1985. The dynamics of three toxic benthic dinoflagellates and the toxicity of ciguateric surgeonfish in French Polynesia. In: Toxic dinoflagellates (Anderson DM, White AW, Baden DG, eds). Elsevier, New York, pp 177-182.

Barbier M, Amzil Z, Mondeguer F, Bhaud Y, Soyer-Gobillard MO, Lassus P. 1999. Okadaic acid and PP2A cellular immunolocalization in Prorocentrum lima (Dinophyceae). Phycologia 38: 41-46.

Besada EG, Loeblich LA, Loeblich AR 3rd. 1982. Observations on tropical, benthic dinoflagellates from ciguatera-endemic areas: Coolia, Gambierdiscus, and Ostreopsis. Bull Mar Sci 32: 723-735.

Biecheler B. 1952. Recherches sur les Péridiniens. Bull Biol France et Belg, Suppl 36: 149.

Bomber JW, Norris DR, Mitchell LE. 1985. Benthic dinoflagellates associated with ciguatera from the Florida Keys. II. Temporal, spatial and substrate heterogeneity of Protocentrum lima. In: Toxic Dinoflagellates (Anderson DM, White AW, Baden DG, eds). Elsevier, New York, pp 45-50.

Carlson RD. 1984. Distribution, periodicity and culture of benthic/epiphytic dinoflagellates in a ciguatera endemic region of the Caribbean. PhD Dissertation. Southern Illinois University, Carbondale, Illinois, USA.

Carty S, Cox ER. 1986. Kansodinium gen. nov. and Durinskia gen. nov.: two genera of freshwater dinoflagellates (Pyrrhophyta). Phycologia 25: 197-204.

Chinain M, Faust MA, Pauillac S. 1999. Morphology and molecular analyses of three toxic species of Gambierdiscus (Dinophyceae): G. pacificus, sp. nov., G. australes, sp. nov., and G. polynesiensis, sp. nov. J Phycol 35: 12821296.

Claparède E, Lachmann J. 1859. Études sur les Infusoires et les Rhizopodes 2. Mém Inst Nat Génev 6: 261-482.

Cortés-Altamirano R, Sierra-Beltrán AP. 2003. Morphology and taxonomy of Prorocentrum mexicanum and reinstatement of Prorocentrum rhathymum (Dinophyceae). J Phycol 39: 221-225.

Dodge JD. 1982. Marine Dinoflagellates of the British Isles. Her Majesty's Stationery Office, London. 
Dujardin F. 1841. Histoire naturelle des Zoophytes Infusoires, comprenant la physiologie et la classification de ces animaux et la maniere de les étudier à l'aide du microscope. Librairie encyclopédique de Roret, Paris.

Elbrächter M, Faust MA. 2002. IOC Taxonomic Reference List of Toxic Plankton Algae: Dinoflagellates (Class Dinoflagellata, Dinophyceae, Phylum Dinophyta) Order Prorcentrales, Intergovernmental Oceanographic Commission of UNESCO. http://ioc.unesco.org/hab/ data4taxlist. Accessed 03 April 2013, pp 23-29.

Faust MA. 1990. Morphologic details of six benthic species of Prorocentrum (Pyrrophyta) from a mangrove island, Twin Cays, Belize, including two new species. J Phycol 26: 548-558.

Faust MA. 1995. Observation of sand-dwelling toxic dinoflagellates (Dinophyceae) from widely differing sites, including two new species. J Phycol 31: 996-1003.

Faust MA. 1996. Dinoflagellates in a mangrove ecosystem, Twin Cays, Belize. Nova Hedwigia 112: 445-458.

Faust MA. 2009. Ciguatera-causing dinoflagellates in a coral-reef mangrove ecosystem, Belize. Atoll Res Bull 569: 1-32.

Faust MA, Gulledge RA. 2002. Identifying harmful marine dinoflagellates. Vol 42. Smithsonian Institution: Contributions from the United. States National Herbarium, Washington, DC.

Faust MA, Larsen J, Moestrup Ø. 1999. Potentially toxic phytoplankton. 3. Genus Prorocentrum (Dinophyceae). In: ICES Identification Leaflets for Plankton (Lindley JA, ed). International Council for the Exploration of the Sea, Copenhagen, Leaflet No. 184.

Faust MA, Morton SL, Quod JP. 1996. Further SEM study of marine dinoflagellates: the genus Ostreopsis (Dinophyceae). J Phycol 32: 1053-1065.

Fenchel T. 1988. Marine plankton food chain. Annu Rev Ecol Syst 18: 19-38.

Flø Jørgensen M, Murray S, Daugbjerg N. 2004a. A new genus of athecate interstitial dinoflagellates, Togula gen. nov., previously encompassed within Amphidinium sensu lato: Inferred from light and electron microscopy and phylogenetic analyses of partial large subunit ribosomal DNA sequences. Phycol Res 52: 284-299.

Flø Jørgensen M, Murray S, Daugbjerg N. 2004b. Amphidinium revisited. I. Redefinition of Amphidinium (Dinophyceae) based on cladistic and molecular phylogenetic analyses. J Phycol 40: 351-365.

Freudenthal HD, Lee JJ. 1963. Glenodinium halli n. sp. and Gyrodinium instriatum n. sp., dinoflagellates from New York Waters. J Protozool 10: 182-189.

Fritz L, Triemer RE. 1985. A rapid simple technique utilizing calcofluor white MR2 for the visualization of dinoflagellate thecal plates. J Phycol 21: 662-664.

Fukuyo Y. 1981. Taxonomical study on benthic dinoflagellates collected in coral reefs. Bull Jap Soc Sci Fish 47: 967-978.

Gilbert PM, Seitzinger S, Heil CA, Burkholder JM, Parrow MW, Codispoti LA, Kelly V. 2005. The role of eutrophication in the global proliferation of harmful algal blooms. Oceanography 18: 198-209.

Godhe A, Rehnstam-Holm AS, Karunasagar I, Karunasagar I. 2002. PCR detection of dinoflagellate cysts in field sediment samples from tropic and temperate environments. Harmful Algae 1: 361-373.

Hallegraeff G M. 1993. A review of harmful algal blooms and their apparent global increase. Phycologia 32: 79-99.

Han MS, Yoo KI. 1983a. A taxonomical study on the dinoflagellates in Jinhae bay, I: Armored and unarmored dinoflagellates. Bull KORDI 5: 37-47.

Han MS, Yoo KI. 1983b. A taxonomical study on the dinoflagellates in Jinhae bay, II: Peridiniales. Bull KORDI 5: 49-67.

Hansen G, Turquet J, Quod JP, Ten-Hage L, Lugomela C, Kyewalyanga M, Hurbungs M, Wawiye P, Ogongo B, Tunje S, Rakotoarinjanahary H. 2001. Potentially Harmful microalgae of the Western Indian Ocean: a Guide Based on a Preliminary Survey. I.O.C. Manuals and Guides 41. Intergovernmental Oceanographic Commission of UNESCO, Copenhagen.

Herdman EC. 1922. Notes on dinoflagellates and other organisms causing discolouration of the sand at Port Erin II. Proc Trans Liverpool Biol Soc 36: 15-30.

Holmes MJ. 1998. Gambierdiscus yasumotoi sp. nov. (Dinophyceae), a toxic benthic dinoflagellate from southeastern Asia. J Phycol 34: 661-668.

Holmes MJ, Lee FC, Teo SLM, Khoo HW. 1998. A survey of benthic dinoflagellates on Singapore Reefs. In: Harmful Algae (Reguera B, Blanco J, Fernandez ML, Wyatt T, eds.). Xunta de Galicia and Intergovernmental Oceanographic Commission of UNESCO, Santiago de Compostela, pp 50-51.

Hoppenrath M. 2000a. A new marine sand-dwelling Prorocentrum species, P. clipeus sp. nov. (Dinophyceae, Prorocentrales) from Helgoland, German Bight, North Sea. Europ J Protistol 36: 29-33.

Hoppenrath M. 2000b. Morphology and taxonomy of six marine sand-dwelling Amphidiniopsis species (Dinophyceae, Peridiniales), four of them new, from the German Bight, North Sea. Phycologia 39: 482-497.

Hoppenrath M, Elbrächter M. 1998. Roscoffia capitata (Dinophyceae) refound: notes on morphology and biology. 
Phycologia 37: 450-457.

Hoppenrath M, Leander BS. 2007. Morphology and phylogeny of the pseudocolonial dinoflagellates Polykrikos lebourae and Polykrikos herdmanae n. sp. Protist 158: 209-227.

Hoppenrath M, Schweikert M, Elbrächter M. 2003. Morphological reinvestigation and characterization of the marine, sand-dwelling dinoflagellate Adenoides eludens (Dinophyceae). Eur J Phycol 38: 385-394.

Hoppenrath M, Elbrächter M, Halliger H, Koeman RPT, Krakhmalnyy A, Surek B, Erler K, Luckas B. 2007a. First records of the benthic, bloom-forming, non-toxic dinoflagellate Thecadinium yashimaense (Dinophyceae) in Europe: with special emphasis on the invasion in the North Sea. Helgol Mar Res 61: 157-165.

Hoppenrath M, Horiguchi T, Miyoshi Y, Selina M, Taylor mFJR, Leander BS. 2007b. Taxonomy, phylogeny, biogeography, and ecology of Sabulodinium undulatum (Dinophyceae), including an emended description of the species. Phycol Res 55: 159-175.

Hoppenrath M, Selina M, Yamaguchi A, Leander B. 2012. Morphology and molecular phylogeny of Amphidiniopsis rotundata sp. nov. (Peridiniales, Dinophyceae), a benthic marine dinoflagellate. Phycologia 51: 157-167.

Horiguchi T. 1995. Amphidinella sedentaria gen. et sp. nov. (Dinophyceae), a new sand-dwelling dinoflagellate from Japan. Phycol Res 43: 93-99.

Horiguchi T, Tamura M, Katsumata K, Yamaguchi A. 2012. Testudodinium gen. nov. (Dinophyceae), a new genus of sand-dwelling dinoflagellates formerly classified in the genus Amphidinium. Phycol Res 60: 137-149.

$\mathrm{Hu}$ T, deFreitas ASW, Doyle J, Jackson D, Marr J, Nixon E, Pleasance S, Quilliam MA, Walter JA, Wright JLC. 1993. New DSP toxin derivatives isolated from toxic mussels and the dinoflagellates, Prorocentrum lima and Prorocentrum concavum. In: Toxic Phytoplankton Blooms in the Sea (Smayda TJ, Shimizu Y, eds). Elsevier, Amsterdam, pp 507-512.

Hulburt EM. 1957. The taxonomy of unarmored Dinophyceae of shallow embayments on Cape Cod, Massachusetts. Biol Bull 112: 196-219.

Iwataki M. 2008. Taxonomy and identification of the armored dinoflagellate genus Heterocapsa (Peridiniales, Dinophyceae). Plankton Benthos Research 3: 135-142.

Jeong HJ, Lim AS, Jang SH, Yih WH, Kang NS, Lee SY, Yoo YD, Kim HS. 2012a. First Report of the epiphytic dinoflagellate Gambierdiscus caribaeus in the temperate waters off Jeju Island, Korea: morphology and molecular characterization. J Eukaryot Microbiol 59: 637-650.

Jeong HJ, Yih W, Kang NS, Lee SY, Yoon EY, Yoo YD, Kim HS,
Kim JH. 2012b. First report of the epiphytic benthic dinoflagellates Coolia canariensis and Coolia malayensis in the waters off Jeju Island, Korea: Morphology and rDNA Sequences. J Eukaryot Microbiol 59: 114-133.

Kang NS, Jeong HJ, Lee SY, Lim AS, Lee MJ, Kim HS, Yih WH. 2013. Morphology and molecular characterization of the epiphytic benthic dinoflagellate Ostreopsis cf. ovata in the temperate waters off Jeju Island, Korea. Harmful Algae 27: 98-112.

Kim HS, Yih WH, Kim JH, Myung G, Jeong HJ. 2011. Abundance of epiphytic dinoflagellates from coastal waters off Jeju Island, Korea during autumn 2009. Ocean Sci J 46: 205-209.

Kofoid CA, Swezy O. 1921. Memoir of the University of California Vol 5: The Free-Living Unarmored Dinoflagellata. University of California Press, Berkeley, CA.

Larsen J. 1985. Algal studies of the Danish Wadden Sea II. A taxonomic study of psammobious dinoflagellates. Opera Bot 79: 14-37.

Larsen J, Nguyen NL. 2004. Potentially toxic microalgae of Vietnamese waters. Opera Bot 140: 5-216.

Larsen J, Patterson DJ. 1990. Some flagellates (Protista) from tropical marine sediments. J Nat Hist 24: 801-937.

Leaw CP, Lim PT, Cheng KW, Ng BK, Usup G. 2010. Morphology and molecular characterization of a new species of thecate benthic dinoflagellate, Coolia malayensis sp. nov. (Dinophyceae). J Phycol 46: 162-171

Lebour MV. 1925. The Dinoflagellates of Northern Seas. Marine Biological Association, Plymouth.

Lee KH, Jeong HJ, Park K, Kang NS, Yoo DY, Lee MJ, Lee JW, Lee S, Kim T, Kim HS, Noh JH. 2013. Morphology and molecular characterization of the epiphytic dinoflagellate Amphidinium massartii, isolated from the temperate waters off Jeju Island, Korea. Algae 28: 213-231.

Lee SG, Park JS, Kim HG. 1993. Taxonomy of marine toxic flagellates occurring in the southern coastal waters of Korea. Bull Nat Fish Res Dev Agency 48: 1-23.

Lehane L, Lewis RJ. 2000. Ciguatera: recent advances but the risk remains. Int J Food Microbiol 61: 91-125.

Lim AS, Jeong HJ, Jang TY, Kang NS, Lee SY, Yoo YD, Kim HS. 2013. Morphology and molecular characterization of the epiphytic dinoflagellate Prorocentrum cf. rhathymum in temperate waters off Jeju Island, Korea. Ocean Sci J 48: 1-17.

Loeblich III AR. 1965. Dinoflagellate nomenclature. Taxon 14: 15-18.

Loeblich III AR, Sherley JL, Schmidt RJ. 1979. The correct position of flagellar insertion in Prorocentrum and description of Prorocentrum rhathymum sp. nov. (Pyrrhophyta). J Plankton Res 1: 113-120. 
Maranda L, Shimizu Y. 1996. Amphidinium operculatum var. nov. gibbosum (Dinophyceae), a free-swimming marine species producing cytotoxic metabolites. J Phycol 32: 873-879.

Marr JC, Jackson AE, McLachlan JL. 1992. Occurrence of Prorocentrum lima, a DSP toxin-producing species from the Atlantic coast Canada. J Appl Phycol 4: 17-24.

Mohammad-Noor N, Daugbjerg N, Moestrup O, Anton A. 2007. Marine epibenthic dinoflagellates from Malaysia: A study of live cultures and preserved samples based on light and scanning electron microscopy. Nordic J Botany 24: 629-690.

Morton SL, Faust MA. 1997. Survey of toxic epiphytic dinoflagellates from the Belizean Barrier Reef Ecosystem. Bull Mar Sci 61: 899-906.

Murray S. 2003. Diversity and phylogenetics of sand-dwelling dinoflagellates from Southern Australia. PhD Dessertation. University of Sydney, Sydney, Australia.

Murray S, Flø Jørgensen M, Daugbjerg N, Rhodes L. 2004. Amphidinium revisited. II. Resolving species boundaries in the Amphidinium operculatum species complex (Dinophyceae), including the descriptions of Amphidinium trulla sp. nov. and Amphidinium gibbosum comb. nov. J Phycol 40: 366-382.

Murray S, Nagahama Y, Fukuyo Y. 2007. Phylogenetic study of benthic, spine-bearing prorocentroids, including Prorocentrum fukuyoi sp. nov. Phycol Res 55: 91-102.

Murray S, Patterson DJ. 2002. The benthic dinoflagellate genus Amphidinium in south-eastern Australian waters, including three new species. Eur J Phycol 37: 279-298.

Murray S, Patterson DJ. 2004. Cabra matta gen. nov., sp. nov., a new benthic, heterotrophic dinoflagellate. Eur J Phycol 39: 229-234.Nakajima I, Oshima Y, Yasumoto T. 1981. Toxicity of benthic dinoflagellates in Okinawa. Bull Jpn Soc Sci Fish 47: 1029-1033.

Nakajima I, Oshima Y, Yasumoto T. 1981. Toxicity of benthic dinoflagellates in Okinawa. Bull Jpn Soc Sci Fish 47: 1029-1033.

Okolodkov YB, Campos-Bautista G, Gárate-Lizárraga I, González-González JAG, Hoppenrath M, Arenas V. 2007. Seasonal changes of benthic and epiphytic dinoflagellates in the Veracruz reef zone, Gulf of Mexico. Aquat Microb Ecol 47: 223-237.

Pang IC, Rho HK, Lee JH, Lie HJ. 1996. Water mass distribution and seasonal circulation northwest of Cheju Island in 1994. J Korean Fish Soc 29: 862-875.

Parsons ML, Preskitt LB. 2007. A survey of epiphytic dinoflagellates from the coastal waters of the island of Hawaii. Harmful Algae 6: 658-669.

Pearce I, Marshall JA, Hallegraeff GM. 2001. Toxic epiphytic dinoflagellates from east coast Tasmania, Australia. In: Harmful algal blooms 2000 (Hallegraeff GM, Blackburn SI, Bolch C J, Lewis RJ, eds). Intergovernmental Oceanographic Commission of UNESCO, Tasmania, Australia, pp 54-57.

Penna A, Vila M, Fraga S, Giacobbe MG, Andreoni F, Riobó P, Vernezi C. 2005. Characterization of Ostreopsis and Coolia (Dinophyceae) isolates in the western mediterranean sea based on morphology, toxicity and internal transcribed spacer 5.8S rDNA sequences. J Phycol 41: 212-225.

Pienaar RN, Sakai H, Horiguchi T. 2007. Description of a new dinoflagellate with a diatom endosymbiont, Durinskia capensis sp. nov. (Peridiniales, Dinophyceae) from South Africa. J Plant Res 120: 247-258.

Pistocchi R, Pezzolesi L, Guerrini F, Vanucci S, Dell'Aversano C, Fattorusso E. 2011. A review on the effects of environmental conditions on growth and toxin production of Ostreopsis ovata. Toxicon 57: 421-428.

Prokic I, Brümmer F, Brigge T, Görtz HD, Gerdts G, Schütt C, Ellbrächter M, Müler WE. 1998. Bacteria of the genus Roseobacter associated with the toxic dinoflagellate Prorocentrum lima. Protist 149: 347-357.

Rhodes L. 2011. World-wide occurrence of the toxic dinoflagellate genus Ostreopsis Schmidt. Toxicon 57: 400-407.

Saburova M, Al-Yamani F, Polikarpov I. 2009. Biodiversity of free-living flagellates in Kuwait's intertidal sediments. BioRisk 3: 97-110.

Schiller J. 1933. Dinoflagellatae (Peridineae). KryptogamenFlora. Akad Verl Leipzig 10: 276-322.

Sechet V, Quillam MA, Rocher G. 1998. Diarrhetic shellfish poisoning (DSP) toxins in Prorocentrum lima in axenic and non-axenic batch culture: detection: detection of new compounds and kinetics of production. In: Harmful Algae (Reguera B, Blanco J, Fernandez ML, Wyatt T, eds). Xunta de Galicia and Intergovernmental Oceanographic Commission of UNESCO, Santiago de Compostela, pp 485-488.

Selina M, Hoppenrath M. 2008. An emended description of Amphidiniopsis arenaria Hoppenrath 2000, based on material from the Sea of Japan. Eur J Protistol 44: 71-79.

Selina MS, Levchenko EV. 2011. Species composition and morphology of dinoflagellates (Dinophyta) of epiphytic assemblages of Peter the Great Bay in the Sea of Japan. Rus J Mar Biol 37: 23-32.

Shim JH. 1994. Illustrated Encyclopedia of Fauna and Flora of Korea, Vol 34. Marine Phytoplankton. Ministry of Education, Seoul. (in Korean)

Shim JH, Shin EY, Choi JK. 1981. A taxonomical study on the dinoflagellates of the coastal waters in the vicinity of 
Yeosu, Korea. J Oceanol Soc Korea 16: 57- 98. (in Korean) Steidinger KA, Tangen K. 1997. Dinoflagellates. In: Identifying Marine Phytoplankton (Tomas CR, ed). Academic Press, San Diego, CA, pp 387-570.

Tamura M, Iwataki M, Horiguchi T. 2005. Heterocapsa psammophila sp. nov. (Peridiniales, Dinophyceae), a new sand-dwelling marine dinoflagellate. Phycol Res 53: 303-311.

Tindall DR, Miller DM, Bomber JW. 1989. Culture and toxicity of dinoflagellates from ciguatera endemic regions of the world. Toxicon 27: 83.

Turquet J. 1997. Etude écologique et toxicologique des Dinophycées benthiques inféodées aux intoxications alimentaires dans le Sud-ouest de l'Océan Indien. PhD Dissertation, Paris VII University, Paris, France.

Turquet J, Quad JP, Couté A, Faust MA. 1998. Assemblage of benthic dinoflagellates and monitoring of harmful species in Reunion Island, SW Indian Ocean, 1993-1996.
In: Harmful algae (Reguera B, Blanco J, Fernández ML, Wyatt T, eds). Xunta de Galicia and Intergovernmental Oceanographic Commission of UNESCO, Santiago de Compostela, pp 44-47.

Yasumoto T, Seino N, Murakami Y, Murata M. 1987. Toxins produced by benthic dinoflagellates. Biol Bull 172: 128-131.

Yoo KI, Lee JB. 1986. Taxonomical studies on dinoflagellates in Masan Bay 1. Genus Prorocentrum Ehrenberg. J Kor Soc Oceanogra 21: 46-55.

Yoshimatsu, S, Toriumi S, Dodge JD. 2004. Morphology and taxonomy of five marine sand-dwelling Thecadinium species (Dinophyceae) from Japan, including four new species: Thecadinium arenarium sp. nov., Thecadinium ovatum sp. nov., Thecadinium striatum sp. nov. and Thecadinium yashimaense sp. nov. Phycol Res 52: 211223. 